\title{
The structural history of the Mont Blanc massif with regard to models for its recent exhumation
}

\section{Journal Article}

Author(s):

Egli, Daniel; Mancktelow, Neil

Publication date:

2013-10

Permanent link:

https://doi.org/10.3929/ethz-b-000074429

Rights / license:

In Copyright - Non-Commercial Use Permitted

Originally published in:

Swiss Journal of Geosciences 106(3), https://doi.org/10.1007/s00015-013-0153-5 


\title{
The structural history of the Mont Blanc massif with regard to models for its recent exhumation
}

\author{
Daniel Egli $\cdot$ Neil Mancktelow
}

Received: 6 November 2012/Accepted: 3 October 2013/Published online: 15 November 2013

(C) Swiss Geological Society 2013

\begin{abstract}
The tectonic evolution of the Mont Blanc range with regard to its cooling and exhumation history has been discussed and debated over many years and is still controversial. Recently, several low-temperature thermochronology studies have determined the cooling history of the massif in considerable detail and various tectonic models proposed to explain the young and fast exhumation signal established from these studies. Here we present detailed field data from the wider Mont Blanc area and assess possible exhumation processes in terms of these field constraints. Our observations indicate that none of the major faults or shear zones around the Mont Blanc massif (i.e. Mont Blanc shear zone, Mont Blanc back-thrust, Penninic thrust) was active in Late Neogene times and that young exhumation is therefore not controlled by movements along these structures. We demonstrate that the position of Mont Blanc in the bend of the western Alps plays an important role in its tectonic history and that simple 2D models are insufficient to explain its evolution. Interference between NW-SE compression and orogenparallel extension along the Rhône-Simplon fault system resulted in a complex regional structural pattern, with
\end{abstract}

Editorial handling: A. G. Milnes.

Electronic supplementary material The online version of this article (doi:10.1007/s00015-013-0153-5) contains supplementary material, which is available to authorized users.

\section{Egli $(\bowtie)$}

Department of Geosciences, Fribourg University, Chemin du Musée 6, 1700 Fribourg, Switzerland e-mail: daniel.egli4@unifr.ch

D. Egli · N. Mancktelow

Geological Institute, ETH Zürich, Sonneggstr. 5, 8092 Zürich, Switzerland strike-slip movements on both sides of the Mont Blanc massif. Young brittle faults are predominantly strike slip without significant vertical offset. The young $(<2 \mathrm{Ma})$ rapid exhumation of Mont Blanc is more broadly distributed and cannot be directly linked to discrete faults bounding the massif. The mechanisms driving this recent accelerated exhumation must similarly be of broader scale.

Keywords Western Alps - Switzerland · France · Italy $\cdot$ Neotectonics $\cdot$ Kinematics $\cdot$ Palaeostress

\section{Introduction}

The Mont Blanc massif is situated in the northern part of the Western Alps at the junction between France, Italy and Switzerland. It is one of a series of basement windows exposing poly-metamorphic Late Proterozoic to Early Palaeozoic gneisses intruded by Late Variscan granitic plutons (von Raumer et al. 1993). These windows expose European crustal rocks covered by Late Palaeozoic to Palaeogene sediments and are referred to as external crystalline massifs. They form a discontinuous chain of elongate, domal culminations following the external part of the Alpine arc, from the Argentera massif in the south-west to the Aar massif in the north-east (Fig. 1). The external crystalline massifs share a similar Neogene exhumation history, although total denudation in the northern external crystalline massifs (Aar-Gastern, Aiguilles Rouges-Mont Blanc) had to be greater than in the southern massifs due to the gradient in thickness of the overlying Penninic nappe pile from 3-5 km in the south to $10-14 \mathrm{~km}$ in the north (Bogdanoff et al. 2000; Vernon et al. 2008). Characteristic for the northern external crystalline massifs is a pronounced local relief and high topography, the highest peak 

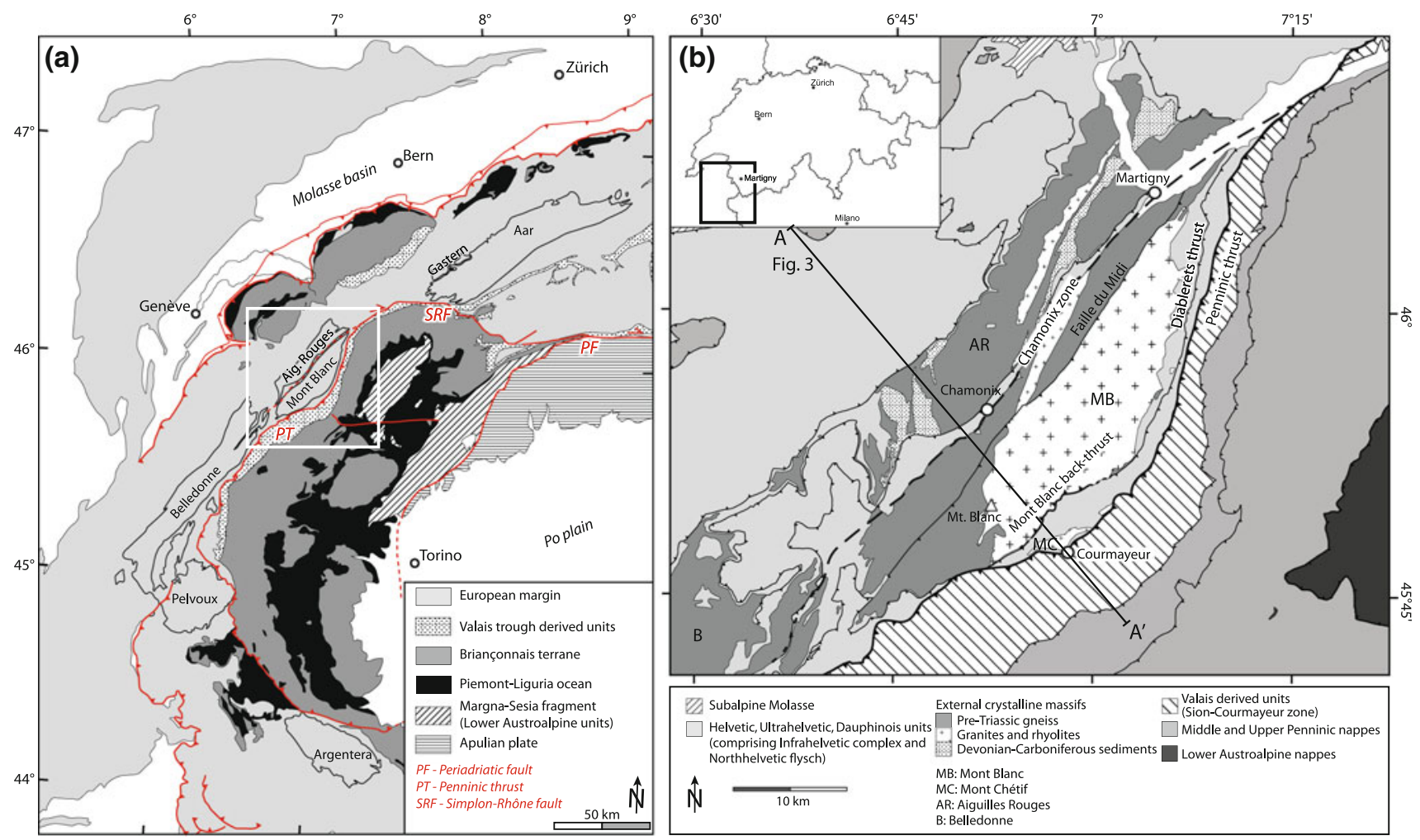

Fig. 1 a Location of the study area showing the major palaeogeographic units of the Central and Western Alps (modified after Froitzheim et al. 1996). b Tectonic map of the study area indicating the major tectonic units and main tectonic lines

of all being in the Mont Blanc massif $(4,808 \mathrm{~m})$. Lowtemperature thermochronology studies provide an extensive data set for estimating exhumation rates in Neogene and Quaternary times (e.g. Soom 1990; Seward and Mancktelow 1994; Fügenschuh et al. 1999; Fügenschuh and Schmid 2003; Leloup et al. 2005; Glotzbach et al. 2008) but the processes leading to this exhumation are still a matter of debate and various models have been proposed. However, all these models include fundamental tectonic assumptions that are only partly confirmed by field observations. The goal of this study is to critically assess the proposed models on the basis of an extensive structural analysis of the Mont Blanc region and thereby to develop a kinematic model for the tectonic evolution of the region, in particular focusing on possible uplift mechanisms. The most important locality names occurring in the text are given in Fig. 2. This work is part of a Ph.D. thesis (Egli 2013), which had the general aim to provide a tectonic context for the Neogene uplift and exhumation history of the Mont Blanc massif. The goal of the project was to supplement the existing knowledge with a field-based study to establish the large-scale tectonic framework and the kinematics of uplift. For that reason, a detailed structural field study was carried out to complement the wide range of already existing data.

\section{Previous work}

\subsection{Geological overview}

The Late Proterozoic to Early Palaeozoic basement rocks of the Mont Blanc massif have undergone a multistage metamorphic and deformational evolution and were subsequently intruded by the calc-alkaline potassic Mont Blanc granite at $305 \pm 2 \mathrm{Ma}$ and in part covered by cogenetic rhyolites (Bussy et al. 1989; von Raumer et al. 1993; von Raumer and Bussy 2004). The early Alpine evolution of the future Mont Blanc area was dominated by sedimentation of Triassic to Palaeogene Helvetic and Ultrahelvetic sedimentary units. Transgression onto highs and deposition in basins of the external domains in Triassic to Middle Jurassic times was followed by sedimentation from Middle Jurassic to Eocene times to build up the distinctive Helvetic and Ultrahelvetic stratigraphy on the southern margin of the former European continent (e.g. Masson et al. 1980; Funk et al. 1987; Kempf and Pfiffner 2004). The end of sedimentation and onset of deformation in the Helvetic domain is marked by the overthrust of Ultrahelvetic imbricate sheets and Penninic nappes. The characteristic Taveyannaz sandstone, rich in andesitic debris, represents the uppermost regional sedimentary unit 


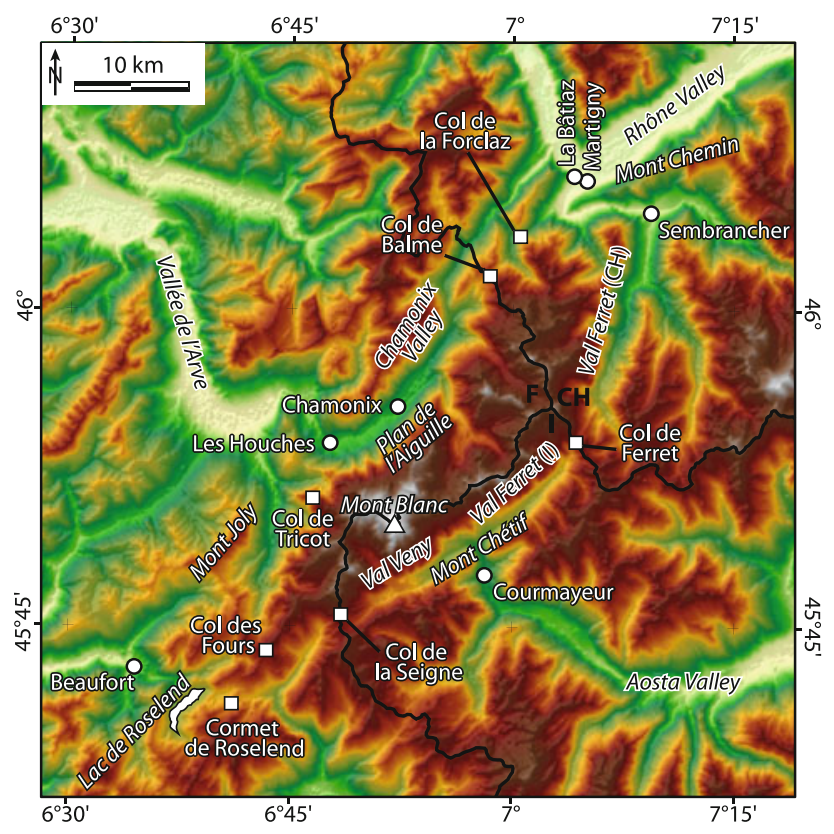

Fig. 2 Digital elevation model of the study area with the most relevant geographical landmarks

and is supposed to be deposited in Early-Middle Oligocene times ( 32-29 Ma, see Lateltin and Müller 1987; Herb 1988; Fischer and Villa 1990; Jeanbourquin and Goy-Eggenberger 1991; Jeanbourquin 1994; Ruffini et al. 1995). In the autochthonous sedimentary sequence of the Aiguilles Rouges massif, the youngest sediments are the Val d'Illiez sandstones, of Early to Middle Oligocene age, which are transitional upwards into the Molasse sediments (e.g. Herb 1988). On-going shortening due to collision between Adria and Europe created the Helvetic fold-and-thrust belt, resulting in approximately $100 \mathrm{~km}$ of $\mathrm{N}-\mathrm{S}$ shortening by internal folding and more discrete thrusting (Burkhard and Sommaruga 1998; Kempf and Pfiffner 2004). Continuing shortening led to uplift and exhumation of deeper parts of the nappe stack, exposing the external crystalline massif basement windows in Neogene times. The present day geometry of the Mont Blanc massif is an elongate domal antiform, plunging moderately $\left(\sim 15-20^{\circ}\right) \mathrm{NE}$ below the Rhône valley in the north, under the Rawil depression (Heim 1921; Burkhard 1988), and moderately $\left(10-15^{\circ}\right)$ to the SSW at the southern end, below the Dauphinois units under a depression between the Mont Blanc and Belledonne massifs.

A general geometric and kinematic model, which is controlled by important SE-directed back-folding simultaneous with $\mathrm{NW}$-directed ductile shearing producing a crustal-scale recumbent antiform, has been proposed (Escher et al. 1993; Steck et al. 1997). In this interpretation, the Mont Blanc massif is considered to be the crystalline core of the Helvetic Morcles fold-nappe. Seward and
Mancktelow (1994) suggested that normal fault reactivation of the Penninic thrust (the basal thrust of the Penninic nappe pile) may also have led to significant amounts of exhumation on the eastern side of the massif. Leloup et al. (2005) proposed an asynchronous two-phase thrust/backthrust model to fit the kinematics of the uplift to the exhumation rates obtained by thermochronology data. They described a SE-dipping Cenozoic shear zone, bringing the NW-verging Mont Blanc onto the Aiguilles Rouges massif: the Mont Blanc shear zone in the Chamonix valley. Their model suggests an initiation of this shear zone at around $12 \mathrm{Ma}$ with a total relative vertical displacement of 4-8 km. Further, the young exhumation was thought to be primarily the result of the initiation (or reactivation) of the Mont Blanc back-thrust at around $2.5 \mathrm{Ma}$, bringing the Mont Blanc basement on top of the Helvetic metasediments in the Italian Val Ferret. Rolland et al. (2007) disagree with the concept of a two-phase model and favour a pop-up model in a dextral transpressive setting in midMiocene times.

\subsection{Tectono-stratigraphic units}

The study area includes the following tectono-stratigraphic units:

1. the Mont Blanc and Aiguilles Rouges basement massifs;

2. their (par-)autochthonus sedimentary cover;

3. the Helvetic (Diablerets and Wildhorn s.l.) nappes, and the equivalent Dauphinois nappes (Subalpine Chains); and

4. the North Penninic Sion-Courmayeur zone.

\subsubsection{Basement}

The Late Carboniferous intrusive rocks of the Mont Blanc granite and associated subvolcanics and rhyolites outcrop over an area of roughly $10 \times 35 \mathrm{~km}$ in the north-eastern parts of the massif and constitute approximately half of the present exposure of the Mont Blanc massif, whereas the rest is largely composed of pre-Alpine gneisses. The Montenvers granite (307 \pm 3 Ma; Bussy and von Raumer 1993) is a slightly older Carboniferous intrusion, which runs NNE-SSW oblique to the Chamonix valley from the area of Col de Balme towards Plan de l'Aiguille, where it is cut off by the Mont Blanc granite. The poly-metamorphic pre-Alpine gneisses are heterogeneously deformed and generally show high-grade fabrics. Alpine deformation in the granite is pervasive on a microscopic scale, although it appears largely undeformed in the field (Bussy 1990; von Raumer and Bussy 2004). Significant Alpine strain was accommodated along localized mylonitic to phyllonitic 
shear zones (e.g. Bellière 1956, 1988; Guermani and Pennacchioni 1998; Rossi et al. 2005; Rolland et al. 2008). Greenschist facies overprint is common close to the overturned basement-cover contact in the Chamonix zone and at the Faille du Midi, which largely follows the granitegneiss boundary and only in the south runs through the preVariscan basement gneiss (von Raumer 1971; Leloup et al. 2005).

The Aiguilles Rouges massif similarly consists of preAlpine basement comprising Carboniferous intrusions, the largest being the Vallorcine granite, which runs parallel to and has a similar age to the Montenvers granite (306 $\pm 1.5 \mathrm{Ma}$; Bussy et al. 2000). A substantial part of the Aiguilles Rouges massif is composed of Devonian and Carboniferous sediments preserved in mildly inverted intra-montane grabens (e.g. von Raumer et al. 1993; Dobmeier 1996; Capuzzo and Bussy 2000).

\subsubsection{Autochthonous cover and Helvetic (and Dauphinois) nappes}

Detailed descriptions of the sedimentary cover of the Mont Blanc massif are given by Trümpy (1951) and Grasmück (1961) for the Val Ferret (i.e. the upright limb of the regional fold-nappe) and by Ayrton (1980) and Epard $(1986$; 1990) for the external parts of Mont Blanc in the Chamonix zone (i.e. the overturned limb of the fold-nappe). The basal units of the cover in some localities are effectively autochthonous, starting with a Triassic transgression onto a pre-Triassic palaeo-topography (e.g. Epard 1990). On the upright limb, the sedimentary sequence has a maximum thickness of 300-500 m. Especially in the upper parts, the sequence is tectonically disturbed, whereas the lower transgressive units often only show very weak deformation. These (par-)autochthonous units are overridden by the allochthonous Helvetic nappes (i.e. the Diablerets and Wildhorn nappes s.l.). Compared to areas north of the Rhône valley, the entire Helvetic sequence is strongly thinned and loses its classic nappe architecture progressively towards the south. The sequence is on average $1-2 \mathrm{~km}$ thick but this thickness varies strongly and is locally tectonically thinned down to only a few tens of metres north of Col de la Seigne below the Penninic Pyramides Calcaires. The inverted limb shows a coherent, although highly deformed, sequence from Triassic-Liassic to Cretaceous (and possibly Eocene) and lies overturned on the upright (par-)autochthonous cover of the Aiguilles Rouges massif. The exact location of the tectonic contact between the sedimentary cover of Mont Blanc and that of Aiguilles Rouges is not clearly established in the Chamonix zone. The Dauphinois Subalpine Chains are the direct continuation of the Helvetic nappes to the south, overlying the southern part of the autochthonous cover of the Mont
Blanc massif but showing a simpler fold-and-thrust belt geometry than the Helvetic nappes (e.g. Pfiffner 2011).

\subsubsection{Sion-Courmayeur zone}

The North Penninic Mesozoic metasediments of the SionCourmayeur zone in the study area are only exposed on the eastern side of the Mont Blanc massif between the Helvetic units and the middle Penninic nappes. The 2,800-3,500 m thick series is described in detail by Trümpy (1954) for the area of the Col de Ferret, at the boundary between Switzerland and Italy, and by Fricker (1960) for the lower parts of the Swiss Val Ferret. The subdivision of the SionCourmayeur zone is debated in the literature and is characterized by many local names (e.g. Trümpy 1951, 1954; Fricker 1960; Antoine 1971; Loprieno et al. 2011). This subdivision is unimportant in the current study and the Sion-Courmayeur zone is simply considered as a single unit. The Sion-Courmayeur zone contains Triassic to Cretaceous sedimentary sequences, as well as EoceneOligocene units, in the imbricate zone of Pierre Avoi (Trümpy 1951). Metamorphic grade reached HP-LT conditions, with a complex and long-lasting tectonometamorphic history (Fügenschuh et al. 1999; Ceriani et al. 2001; Fügenschuh and Schmid 2003). Loprieno et al. (2011) investigated the deformation and metamorphic history of the Sion-Courmayeur zone in the southern parts of the study area. They describe intense pre-Oligocene polyphase folding and thrusting, followed by thrusting of the whole complex over the Dauphinois-Helvetic domain along the Penninic (or Roselend) thrust. The internal North Penninic units underwent a polyphase metamorphic history with a HP-LT phase followed by a HP-HT stage, whereas the external Sion-Courmayeur zone was only affected by HP-LT metamorphism (Goffé and Bousquet 1997; Goffé et al. 2004; Oberhänsli et al. 2004; Loprieno et al. 2011).

\subsection{Major tectonic structures}

The Mont Blanc massif is framed by major valleys that are associated with major zones of Alpine deformation. On the internal side in the Val Ferret and Val Veny, the Penninic thrust marks the internal boundary of the Helvetic zone, which is reduced to the very narrow and highly sheared "root zone" of the Helvetic nappes between the Penninic thrust and the Mont Blanc basement. More locally, a steeply NW dipping system of shear zones (the Mont Blanc back-thrust) tectonically places the Mont Blanc basement on top of its sedimentary cover. The external border of the Mont Blanc massif is defined by the Chamonix valley, which follows a deformation zone referred to here as the Chamonix zone (e.g. Paréjas 1922). Figure 3 shows a cross-section through the southern Mont Blanc and 


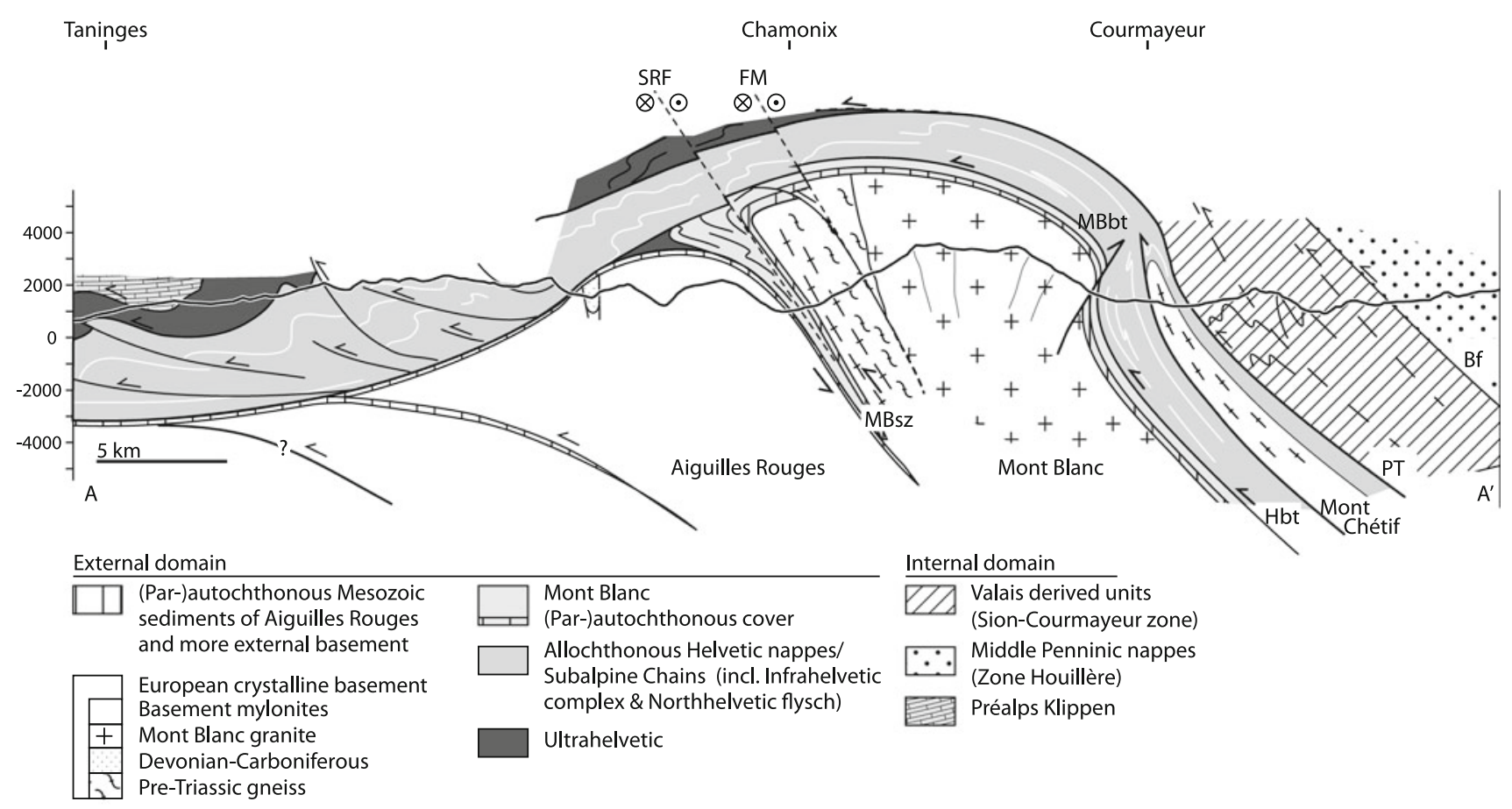

Fig. 3 NW-SE section through the southern Mont Blanc and Aiguilles Rouges massifs. Trace of section is given in Fig. 1b. The section shows the positions of the main fault zones discussed in the

Aiguilles Rouges massifs showing the location of the major structures.

\subsubsection{Penninic thrust}

The Penninic thrust or Pennine Frontal Thrust (Chevauchement Pennique frontal, Argand 1911, 1916), separating the internal (Sion-Courmayeur zone and Briançonnais units) and the external (Helvetic and Ultrahelvetic) part of the Alps is a major fault zone around the bend of the western Alps (e.g. Schmid et al. 2004). The Penninic thrust is here defined as the current erosional front of the basal thrust of the Penninic nappe pile. This thrust front not only separates two palaeogeographically different domains but also marks a metamorphic boundary between the HP-LT Sion-Courmayeur zone and the low-grade Helvetic meta-sediments (e.g. Perello et al. 1999). At the southern tip of the Mont Blanc massif, the Penninic thrust has a km-scale mean dip of $\sim 25^{\circ}$ and is therefore slightly steeper than the Helvetic/ Dauphinois meta-sediments in its footwall (Mugnier et al. 1993). Kinematics along the Penninic thrust is still a matter of debate, especially regarding the latest history. Initial activity on the Penninic thrust has been described to be of Eocene-Oligocene age during underthrusting of the European passive margin beneath the Penninic domain (Ceriani et al. 2001; Simon-Labric et al. 2009). Strong, approximately NW-directed shear dominated along the Penninic text: SRF Simplon-Rhône fault, FM Faille du Midi, MBsz Mont Blanc shear zone, MBbt Mont Blanc back-thrust, Hbt Helvetic basal thrust, $P T$ Penninic thrust, $B f$ Briançonnais front

thrust in the northern parts of the study area. More to the south, the shear was WNW-directed and deformed the Helvetic/Dauphinois units in its footwall over a considerable time span of 32-17 Ma (D3 phase of Fügenschuh et al. 1999; Loprieno et al. 2011). Seward and Mancktelow (1994) proposed Late Neogene normal fault reactivation in the vicinity of the Penninic thrust in the northern areas on the basis of a low-temperature thermochronology study. Structural evidence for late normal faulting has been documented south and east of the Mont Blanc massif on the Penninic thrust (e.g. Sue and Tricart 1999) and on more internal structures (e.g. the Briançonnais front, e.g. Fügenschuh et al. 1999; Malusa et al. 2005). In the current study area, the Penninic thrust can best be defined as the protolith boundary between the sediments of the Sion-Courmayeur zone and the Helvetic units of the "root zone", often marked by a thick Triassic evaporite layer. However, where the Triassic detachment horizon is absent, it is structurally not discernible as a discrete fault. In that case, it is a kmwide deformation zone with nearly uniform and strong shearing extending from the Sion-Courmayeur zone into the Helvetic units.

\subsubsection{Mont Blanc back-thrust}

In the Italian Val Ferret and Val Veny, over a distance of approximately $10 \mathrm{~km}$, the basement-cover contact is 
overturned and dipping steeply towards the NW. This feature has been described by several previous authors (e.g. Antoine et al. 1975; Escher et al. 1993; Leloup et al. 2005) with different interpretations. Most recently it is referred to as the Mont Blanc back-thrust and described as a series of steeply NW-dipping thrust faults bringing the Mont Blanc granite on top of overturned Jurassic metasediments (Fig. 4a; cf. Guermani and Pennacchioni 1998; Leloup et al. 2005). For others, it is mainly a back-fold, locally overturning the basement-cover contact (Évêque back-fold, Escher et al. 1993, 1997; Steck et al. 2001). Within the Mont Blanc granite, associated high-strain zones involving both ductile shear zones and cataclasites can be found (Fig. 4b). They are discussed in detail by Guermani and Pennacchioni (1998), who describe intense deformation inside the granite body with ductile shear following brittle precursors and showing SE-verging reverse kinematics.
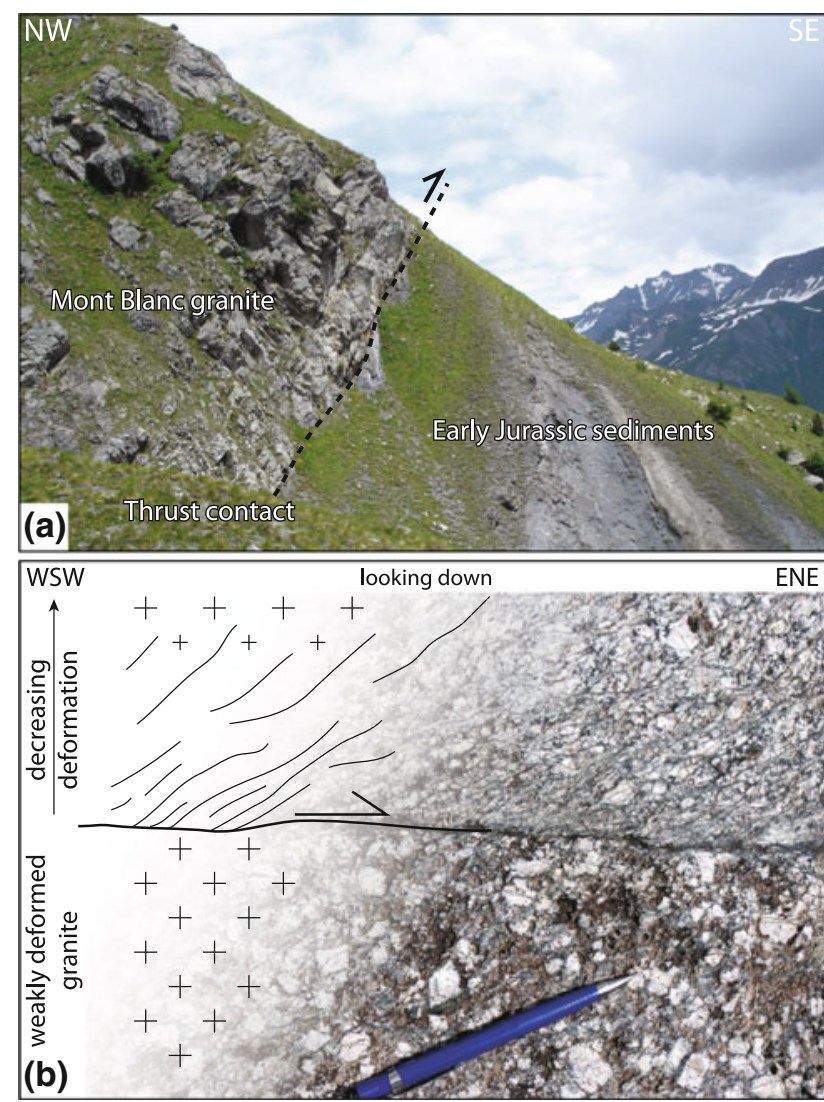

Fig. 4 Deformation related to the Mont Blanc back-thrust. a Main thrust contact between the Mont Blanc granite and its original Mesozoic cover units. b Discrete shear-zone inside the mediumgrained Mont Blanc granite. Orientation of the shear-zone is 346/80 (dip direction/dip) and the lineation is 270/53 (trend/plunge) resulting in oblique reverse-dextral kinematics. Locations: $\mathbf{a}$ is from the path Planpincieux-Rifugo Bocalatte [564653/077013], b is from the foot of the Thoules Glacier between Pavillon and Point Helbronner [560289/076075] (Coordinates of all localities are given in Swiss coordinates)
The role of the Mont Blanc back-thrust in the uplift history of the massif is controversial, especially regarding the time of activity. ${ }^{40} \mathrm{Ar} /{ }^{39} \mathrm{Ar}$-ages of synkinematic white mica from shear zones related to the Mont Blanc back-thrust yield ages of $\sim 16 \mathrm{Ma}$, suggesting activity on these shear zones to be at (if the ages are formation ages) or before (if they are cooling ages) this time (Rolland et al. 2008). Leloup et al. $(2005,2007)$ on the other hand argue that even though activity might have initiated in mid-Miocene, young movements $(<4 \mathrm{Ma})$ also occurred. They base these arguments on the brittle character of the structure as well as on decreasing AFT ages along the Mont Blanc tunnel towards the SE. However, a more recent thermochronology study by Glotzbach et al. (2008) contradicts these data, claiming that there is no jump in ages across the Mont Blanc back-thrust along the tunnel transect and therefore that no vertical offset took place across this structure after $4 \mathrm{Ma}$.

\subsubsection{Chamonix zone}

From Martigny in the northeast to the area of Les Houches in the southwest, a narrow strip of Mesozoic metasediments runs along the Chamonix valley and forms what is commonly referred to as the Chamonix zone (Paréjas 1922). This narrow and highly deformed zone separates the Mont Blanc from the Aiguilles Rouges massif. The largest part of the zone is covered with glacial debris in the deeply incised Chamonix valley and detailed study of the rocks is, with few exceptions, restricted to the passes at the northern and southern extremities of the valley [i.e. Col de la Forclaz and Col de Balme (N), Col du Mont Lachat and $\mathrm{Col}$ du Tricot (S)]. These passes mark the boundary of the Mont Blanc basement to the Helvetic cover metasediments, with a clear topographic expression reflecting the change in resistance of the rocks to erosion. The basement-cover contact itself is clearly an overturned stratigraphic contact, as proposed in earlier studies (e.g. Paréjas 1922; Epard 1986; Bellière 1988). However, it is also strongly sheared, corresponding to the so-called Mont Blanc shear zone (Leloup et al. 2005). The work of Epard (1986) gives a detailed description of the stratigraphic succession from the region of $\mathrm{Col}$ de Tricot and refutes the presence of a discrete tectonic thrust contact between the Mont Blanc basement and the Mesozoic sediments, as described by various earlier authors (e.g. Eltchaninoff-Lancelot et al. 1982; Butler 1983; Gourlay and Ricou 1983; Platt 1984; Leloup et al. 2005). The main tectonic contact between Mont Blanc and Aiguilles Rouges and their respective sedimentary cover therefore lies not directly at the basement-cover boundary but more externally (i.e. to the northwest) in the cover units ("zone de suture médiane" of Ayrton 1980). Earlier studies (e.g. Ayrton 1980; Gourlay 
and Ricou 1983) considered that late strike-slip movements along the Chamonix zone played a major role in the younger tectonic history of the region. This dextral strikeslip displacement corresponds, at least in part, to the prolongation of the dextral Rhône-Simplon fault, which can be morphologically traced from Martigny over the Col de Forclaz and the Col de Balme into the Chamonix valley (e.g. Hubbard and Mancktelow 1992).

\section{Our results}

\subsection{Overall structural framework}

The Mont Blanc region underwent a polyphase Alpine deformation history, resulting in complex overprinting patterns of schistosities and folds. The structural generalizations in the following section describe the overall structural framework of the larger Mont Blanc area, which are documented in Egli (2013). Numbering of structures D1-D3 is used to distinguish the local relative chronology of the varying discernible structures and is not necessarily meant to define separate regional deformation phases. In particular, more internal units (e.g. the Penninic units) may have additional earlier deformation phases not considered here (e.g. Steck and Hunziker 1994; Fügenschuh et al. 1999; Loprieno et al. 2011).

\subsubsection{Deformation phase D1}

The youngest sedimentary units in the Helvetic realm are the turbiditic Taveyannaz sandstones deposited in the more internal Helvetic realm and the Val d'Illiez sandstones in the autochthonous cover units of the Aiguilles Rouges massif (e.g. Lateltin and Müller 1987). Volcaniclastic components of the Taveyannaz sandstones, considered to have originated from Periadriatic plutonism, have been dated to be of early Oligocene age ( 32 Ma) and were deposited between $\sim 32-29$ Ma (Fischer and Villa 1990; Ruffini et al. 1995). The more external Val d'Illiez sandstones show a transition to Molasse sediments of Middle Oligocene age (Lateltin and Müller 1987; Herb 1988). Deposition of these syn-orogenic sediments therefore marks the earliest time that the Helvetic realm could have entered the orogenic wedge. Deformation in the Mont Blanc area started with the arrival of the Ultrahelvetic units as they were thrust over the future Morcles nappe, but without the production of clearly discernible structures in the footwall. The first pervasive Alpine structure in the area is a lower greenschist facies schistosity that presumably resulted from burial of the Helvetic proto-nappes beneath Ultrahelvetic and Penninic units and the formation of the large recumbent Morcles fold-nappe (Masson et al. 1980;
Burkhard 1988; Escher et al. 1993; Huon et al. 1994). Apart from this lower-greenschist schistosity, D1 structures such as meso-scale folds or stretching lineations are rarely observed because they are strongly overprinted by subsequent deformation, although there are marked differences in intensity of deformation along the basement-cover boundary. The D1 schistosity generally follows the shape of the Mont Blanc massif. Shear affected the basement rocks and its cover in the Chamonix zone (corresponding to the Mont Blanc shear zone), as well as the allochthonous units on the eastern side of the massif. In contrast, the (par)autochthonous cover on the eastern side of the basement is in places practically undeformed, with well-preserved fossils and sedimentary structures (Fig. 5a, b). However, along this cover contact, the style and intensity of deformation changes dramatically. The weakly deformed (par)autochthonous sediments are most prominent in the northern and southern parts of the upright limb, in the Swiss Val Ferret and the areas west of Col de la Seigne. In the middle parts, between Petit Col de Ferret and mid-Val Veny, the contact is deformed and often obliterated by the Mont Blanc back-thrust. Close to Petit Col de Ferret, lenses of marble inside the sheared granite indicate strong ductile overprint of the sedimentary basement-cover contact (Fig. 5c).

\subsubsection{Deformation phase D2}

The second discernible deformation is mainly expressed as another well-developed lower greenschist facies schistosity associated with strong shearing. Apart from the weakly deformed (par-)autochthonous units mentioned above, the S2 schistosity is nearly ubiquitous throughout the study area, although it is not equally developed in all areas. D2 can form tight to isoclinal folds on various scales and, depending on the lithology, a characteristic $\mathrm{mm}$ - to $\mathrm{cm}$ spaced crenulation cleavage is developed (Fig. 6a-c). The intense D2 crenulation cleavage often exhibits a mineral stretching lineation and displays clear shear sense criteria relative to this lineation (Fig. 6d). S2 generally dips moderately steep towards the SE with some systematic variation. The associated stretching lineation also varies in orientation, from a near down-dip SE plunge to a more shallow E-W trending orientation (for details, see Egli 2013). The strike of S2 east of the Mont Blanc massif mimics the shape of the eastern basement-cover boundary and therefore shows a change in strike from NNE-SSW in the north to NE-SW in the southern half of the massif. The stretching lineations show a similar change in orientation from almost down-dip in the northern part to a much shallower plunge, dominantly with a direction towards 70-90 . Sense of shear is top-to-(W)NW where lineations are down-dip and oblique reverse dextral top-to-W where 

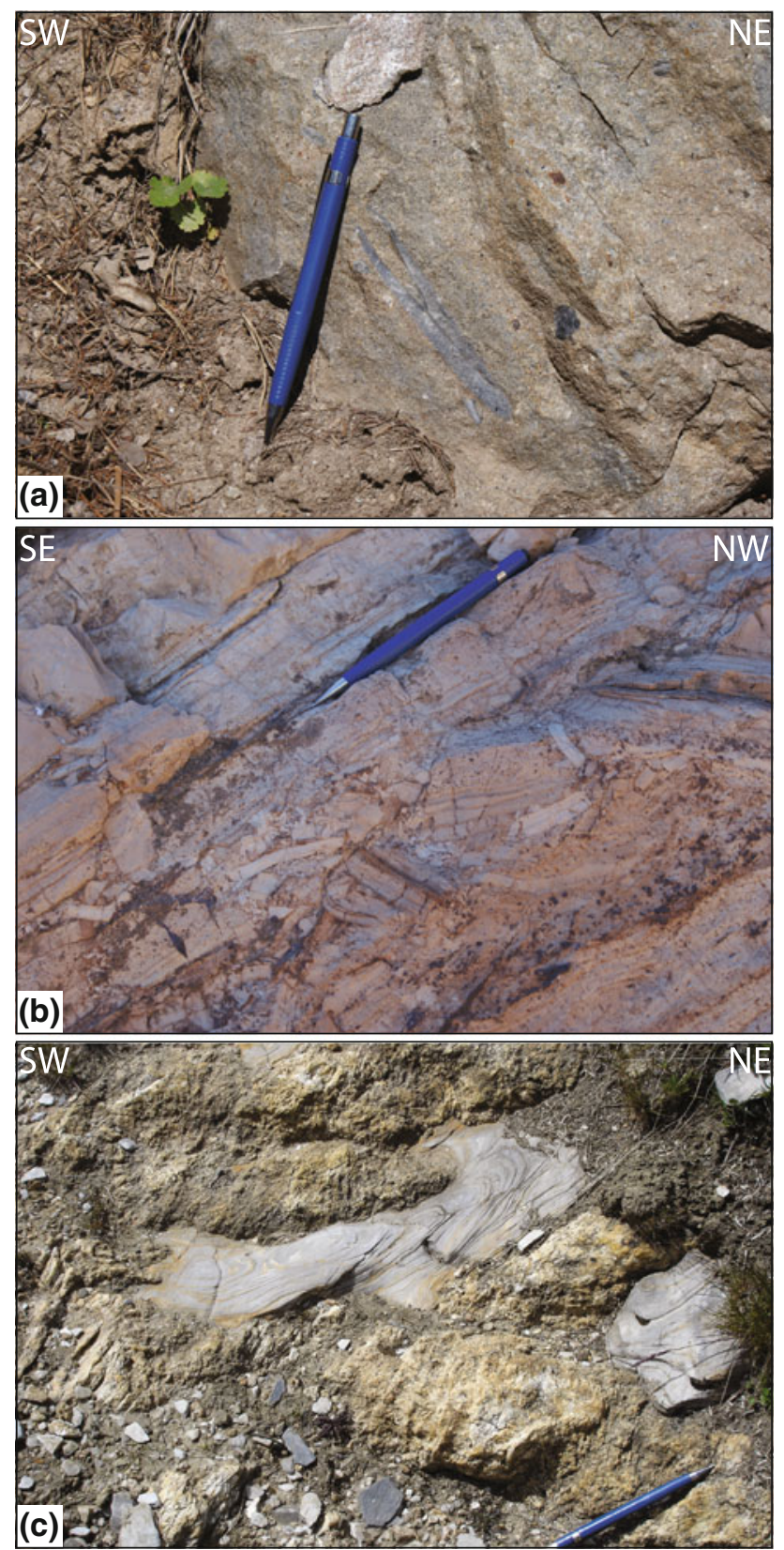

Fig. 5 a Weakly deformed Liassic cover of the Mont Blanc basement close to Col des Planches southeast of Martigny [575519/104400]. b Preserved soft-sediment deformation structures in autochthonous dolostone east of Col des Fours [544961/064484]. c Marble lenses in basement rocks between Pt. Col de Ferret and Bivaccio Fiorio [571092/082839]

lineations are shallow. It appears that the orientation of the D2 schistosity is strongly controlled by the pre-existing geometry of the crystalline basement block of the Mont Blanc massif. Although most parts of the study area are affected by D2, a certain concentration of shear can be observed on major shear zones. The most prominent synD2 shear-zone occurs at the transition from the weakly deformed lower parts of the (par-)autochthonous cover to the strongly deformed allochthonous Helvetic units, observable in the north-eastern and south-western extremities of the massif. This would correspond in its structural position to the Diablerets thrust described, for instance, in the Swiss Val Ferret (Masson et al. 1980; Crespo-Blanc et al. 1995). In the south, the (par-)autochthonous sequence is incomplete and the shear zone, which can be considered as the basal thrust of the Helvetic nappes, is probably in effect equivalent to the Diablerets thrust. Considering an in-sequence formation of the Helvetic nappe stack (e.g. Masson et al. 1980; Burkhard 1988), the Diablerets thrust must have first been active during D1, but on-going D2 outof-sequence shear of the initial thrust, as well as the Penninic thrust and the Chamonix zone, largely obliterated earlier structures. This relationship can be well observed in the region of Col des Fours at the southernmost tip of the Mont Blanc massif. There the transition from undeformed Triassic dolostones to moderately sheared and strongly foliated metasediments is marked by several metres of strongly sheared rocks (Fig. 7). However, to the north, in the region of Sembrancher, the (par-)autochthonous sequence is complete up to the level of the Upper Jurassic (Malm) but is increasingly affected by D2 shear in the footwall of the Diablerets thrust. Activity on the Diablerets thrust has been dated in the Swiss areas to last from approximately 28-15 Ma (Crespo-Blanc et al. 1995; Kirschner et al. 1995). S1-S2 overprinting relationships and F2 fold vergences are identical on both limbs of the Mont Blanc fold-nappe, establishing that shearing and shortening during D2 post-dated the initial nappe formation.

\subsubsection{Deformation phase D3}

The end of ductile shearing is marked by subsequent folding of the $\mathrm{S} 2$ foliation. It is mainly expressed as upright open folds, infrequently accompanied by a spaced crenulation cleavage (Fig. 8a). It is distinguishable from D2 by its generally different fold style (more kinky, lower amplitude to wavelength ratio) and a different orientation of the axial plane (and axial plane schistosity when developed; Fig. 8b). While D2 clearly expresses $\sim$ NWdirected shear with $\sim \mathrm{NE}-\mathrm{SW}$ trending schistosity and axial planes, the subvertical D3 axial planes are striking N$\mathrm{S}$ and overprint the S2 schistosity and related shear structures. D3 folds are most common in the area of Courmayeur but are also present in the Chamonix zone, most prominently in the area of Col de Balme. Overprinting relationships of the $\mathrm{D} 2$ foliation suggests that the local overturning of S2 in the vicinity of the Mont Blanc back-thrust has to have taken place before D3 folding. Between Mont Chétif and the Mont Blanc back-thrust, the $\mathrm{S} 2$ is arranged in a fan-like manner, dipping to the SE close to Mont Chétif and to the NW below the Mont Blanc back- 

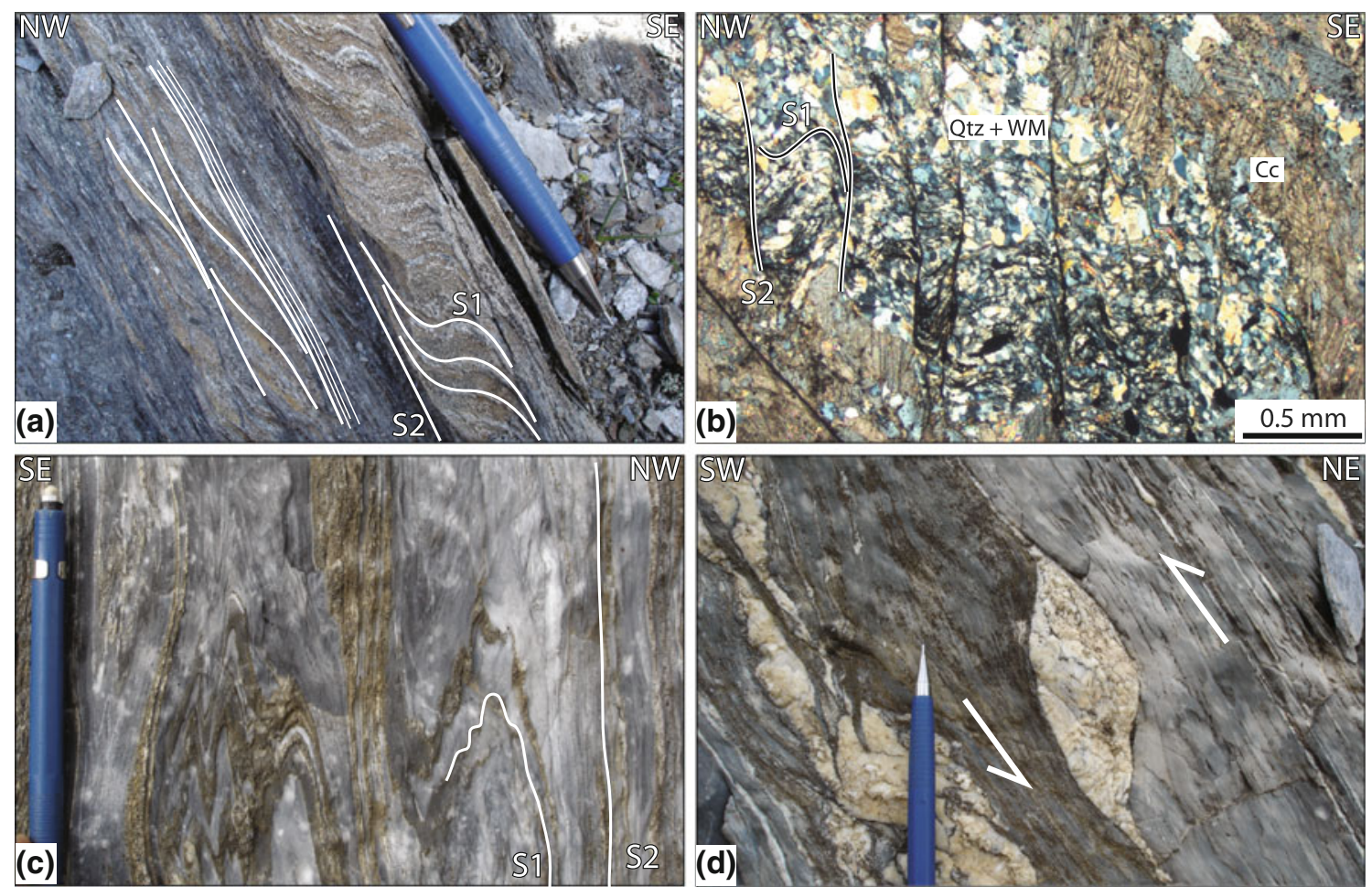

Fig. 6 Structures related to the D2 deformation phase: a Characteristic D2 spaced crenulation cleavage on the mesoscale [571815/ 082407]. b The same cleavage on the microscale. c D2 isoclinal

thrust. Shortening of this broad fan led to buckling of S2 and formation of D3 folds with opposing vergence on either side (Fig. 8c, d), due to the different initial orientations of the folded S2 schistosity. D3 axial planes are not overturned by the Mont Blanc back-thrust, suggesting that D3 took place after back-thrusting/folding.

\subsection{Kinematic analysis and direction of shear}

The kinematic implications derived from the structural observations described in the previous section are described in this following Chapter, which is based on a more detailed discussion in Egli (2013). Due to the variety of the structures found in area II (see map Fig. 9), this area is described at the end of this section in order to allow a direct comparison with the other areas.

\subsubsection{Swiss Val Ferret: "Root zone"}

In the northernmost part of the Swiss Val Ferret, clear S0$\mathrm{S} 1-\mathrm{S} 2$ relationships are preserved. S2 is consistently steeper than S1, which itself is steeper than the bedding S0. Dip direction is very consistently towards $\sim 120^{\circ}$, whereas the dip is around $40^{\circ}$ for $\mathrm{S} 1$ and around $60^{\circ}$ for $\mathrm{S} 2$. There is a strong gradient in deformation from the basement, which shows very little Alpine overprint, into the higher units. folding of S1 in impure Upper Jurassic limestone [572436/085782]. d Asymmetric quartz-boudin indicating top-to-NW sense of shear [572410/085792]

The lowermost parts of the (par-)autochthonous rocks also show very little deformation, with a widely spaced S1. From the Early Jurassic marls (middle Liassic) upwards, S1 is penetrative and sub-parallel to So, forming a composite cleavage S0/S1. The first S2 overprint can be observed at the base of the Late Jurassic limestones (Malm), which shows tight D2 folds and often the typical spaced crenulation cleavage. These units immediately below the Diablerets thrust are highly sheared, although the dominant schistosity is still S1 and D2 is expressed as dm-sized folds. Farther up, the dominant schistosity is S2, which forms a spaced crenulation cleavage, and $\mathrm{S} 1$ is only visible in microlithons. The deformation is uniform across the Penninic thrust indicating collective shear of the footwall and hanging wall of the Penninic thrust during out-of-sequence thrusting. Further to the south, between Sembrancher and Col de Ferret, deformation in the Helvetic units is more uniform and S2 clearly dominates the structural appearance. The stretching lineation plunges towards $\sim 120-150^{\circ}$ with a tendency to a more E-directed plunge towards the south. Deformation in the (par-)autochthonous Helvetic units related to D1 and in the Sion-Courmayeur zone away from the Penninic thrust often shows SSE-S plunging lineations, indicating an earlier phase of thrusting to the NNW with a sinistral component along the internal boundary of the massif (Fig. 9 area I). 

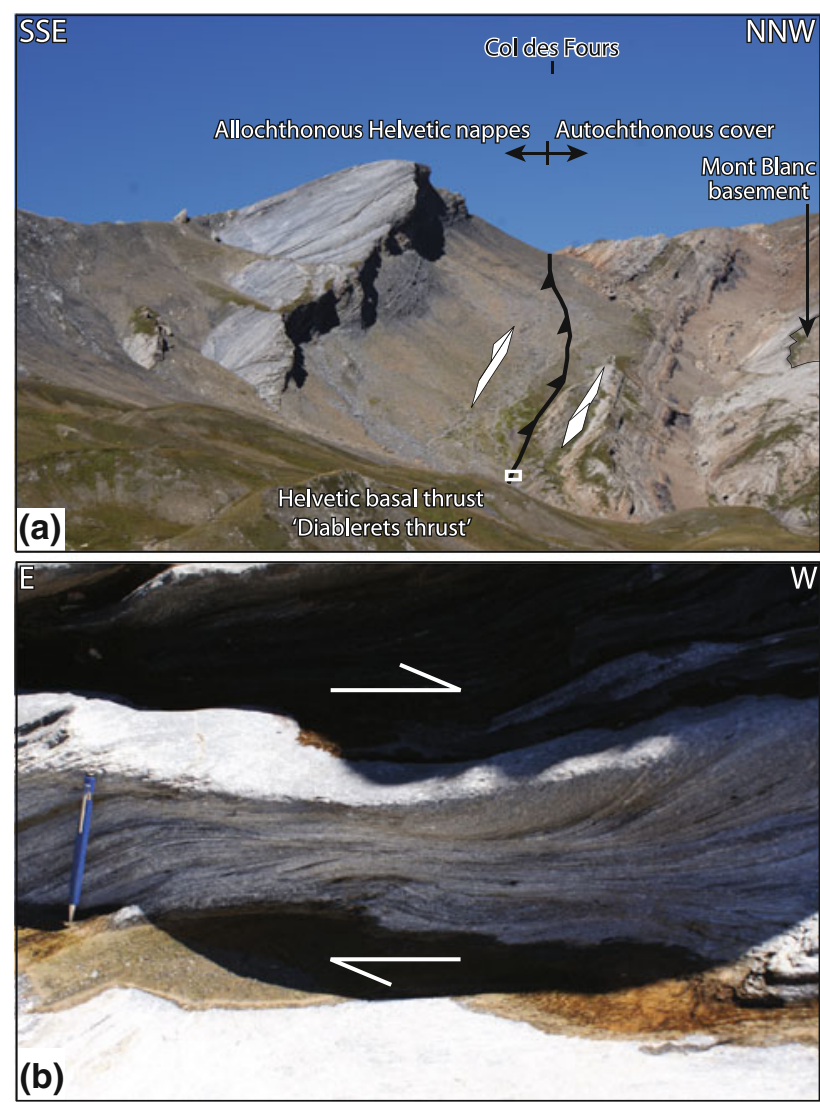

Fig. 7 a Panoramic view of the Diablerets thrust and the Col des Fours [545941/064063]. b Detail photograph of calcareous sandstone at the high-strain contact between autochthonous units and the overlying allochthonous nappe [544938/064421]

\subsubsection{Col de la Seigne: Cormet de Roselend (south end of Mt. Blanc massif)}

At the southern tip of the Mont Blanc massif, the dominant structure is the S2 crenulation cleavage, similar to further north. However, two sets of lineations can be observed across the Penninic thrust and into the Helvetic units. Again, the Sion-Courmayeur zone immediately above the Penninic thrust and the underlying Helvetic units are equally deformed and show the same deformation features. The main shearing is towards the W-WSW on SE dipping planes, with a marked dextral strike-slip component (Fig. 9 area III, plot a). The second set of stretching lineations plunges shallowly towards S-SSW (Fig. 9 area III, plot b). In some outcrops it is possible to demonstrate that the latter lineation reflects younger movement with dextral strikeslip kinematics and with a minor SE-down component. There is an obvious difference in the movement direction between the Helvetic units southeast of Lac de Roselend and those around and northwest of Lac de Roselend. This change coincides with the southward continuation of the Faille du Midi, forming the contact between the upright and overturned limbs of a large-scale fold. In the upright south-eastern limb, the Helvetic units show a W-directed shear with a dextral transcurrent component, as mentioned above. In the overturned units to the NW, D2 shows top-toWNW shear with $\sim$ down-dip lineations on planes dipping on average 140/40 (Fig. 9 area IV). These orientations are very similar to structures in the Swiss Val Ferret and are also typical of the entire Chamonix valley.

\subsubsection{Chamonix zone}

Along the Chamonix zone, deformation appears very uniform with the schistosity dipping on average $40-60^{\circ}$ towards $110-130^{\circ}$ and lineations plunging generally $40-50^{\circ}$ towards $90-110^{\circ}$. The WNW-W directed shear therefore has a minor dextral component, which is strongest in the basement mylonites directly east of Chamonix (Fig. 9 areas V-VII). S2 generally is the dominant fabric with a well-developed stretching lineation. D2 infrequently also produces meso-scale folds without the development of a spaced crenulation cleavage S2. In the Chamonix zone, and in particular on the eastern margin of the Aiguilles Rouges basement, ambivalent shear senses on steep foliations indicating both top-NW and top-SE senses of shear, with a dextral component, can be observed. Sometimes such localized shear structures form at a distinct angle to each other, with the NW-directed shear zones having a shallower dip. In these examples, it is possible to demonstrate that they are conjugate shear zones and are therefore interpreted to have formed synchronously in a near-coaxial setting (Fig. 10 plot VIII a). In these conjugate shear zones, the SE-down shear-bands are dominant close to the basement-cover contact, suggesting a relative uplift of the Aiguilles Rouges massif with respect to the Chamonix zone and Mont Blanc massif in an overall compressional setting. The most impressive exposure of predominant SEdown shear zones is located at La Bâtiaz in the Rhône valley, where the basement-cover contact is marked by m-wide phyllonitic zones with SE side down sense of shear, accompanied by minor conjugate zones. These shear zones overprint a presumably Alpine fabric, which indicates top-to-NW direction of transport. This late SE-down overprint extends into the cover rocks of the Chamonix zone for a few tens of metres. The meta-sediments of the Chamonix zone between La Bâtiaz and Col de Forclaz are differently deformed than further to the south. The strongly mylonitic limestones have shallow stretching lineations and are folded by two kinds of late folds (1) with subvertical fold axes and axial planes and (2) with shallowly plunging fold axes and shallow dipping axial planes, interfering in an open dome-and-basin interference pattern (Fig. 10 plot VIII b). Detailed descriptions of the structures at La Bâtiaz are given by Ayrton (1980) and Egli (2013). 


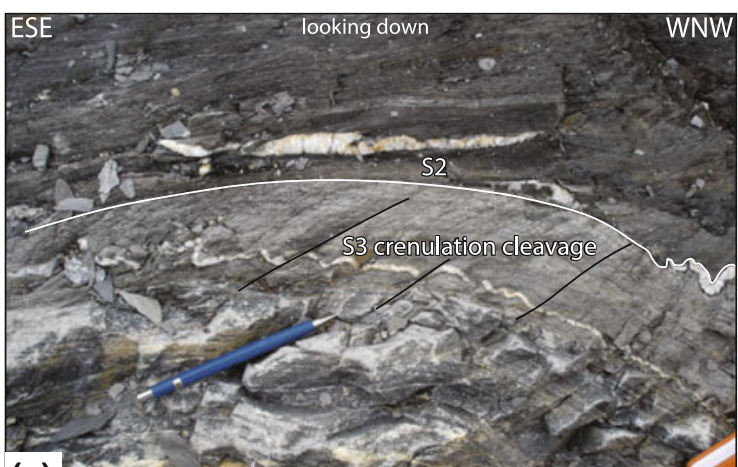

(a)

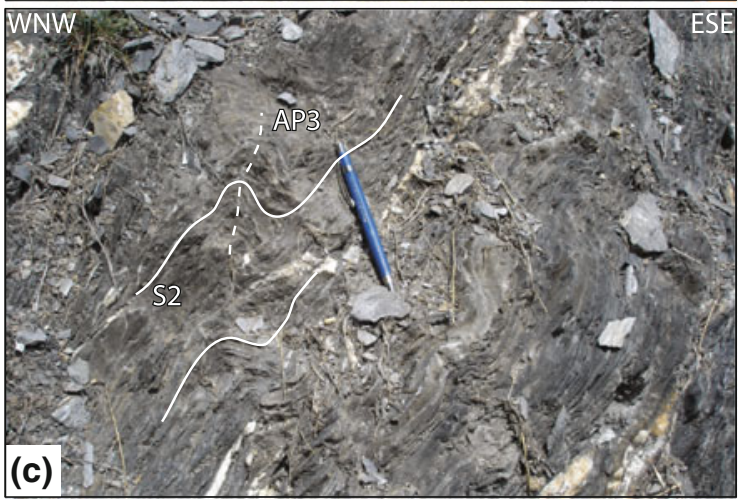

Fig. 8 Structures related to the D3 deformation phase. a Spaced crenulation cleavage overprinting S2 (S2 325/64, S3 299/75) [566367/077432]. b Stereographic projection of D3 axial planes, S3 and D3 fold axes measured in the Swiss and Italian Val Ferret. c D3

\subsubsection{Courmayeur area}

In the Italian Val Ferret the structural appearance is more complex due to the influence of the Évêque back-fold and the Mont Blanc back-thrust. While the structures in the Sion-Courmayeur zone still indicate NW-directed shear with $\sim$ down-dip lineations, the Helvetic domain is less uniformly deformed (Fig. 10 plot II a-d). The dominant S2 schistosity is arranged in a fan-like manner, with a NWdipping foliation below the Mont Blanc back-thrust and a SE-dipping foliation in the footwall of the Penninic thrust. An increased dextral transcurrent shear-component is reflected in shallower lineations, plunging to the E-NE on SE-dipping planes and plunging to the $\mathrm{W}-\mathrm{SW}$ on NWdipping planes. Further to the south, towards the region of Cormet de Roselend, transcurrent movements clearly dominate the structural appearance.

The Mont Chétif basement slice is heterogeneously deformed, ranging from mylonites, through weakly foliated domains, to effectively undeformed rocks, mainly consisting of rhyolites and granites. Apart from the late brittle overprint, basically three types of deformation can be distinguished in the Mont Chétif: (a) a strong mylonitic fabric with oblique dextral-reverse shear as described for D2 in the southern part, (b) metre-scale mylonitic or

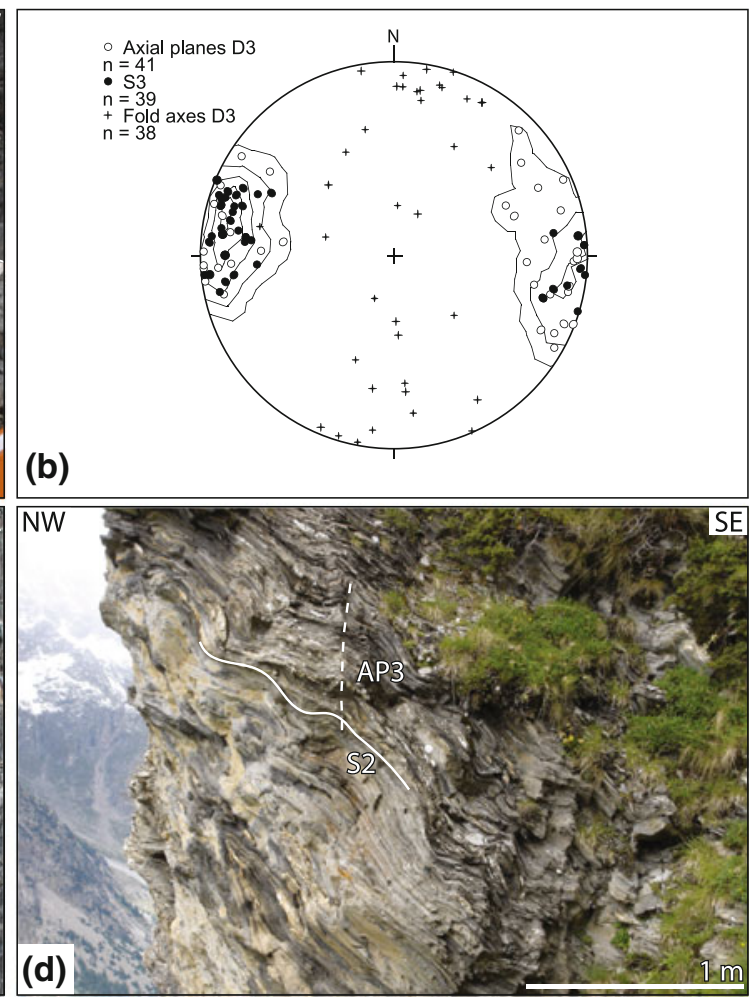

folds on the western side of Val Ferret [566494/075673]. d D3 folds on the eastern side of Val Ferret, with opposite vergence to those shown in c due to differently oriented S2 [561666/074294]

phyllonitic shear zones that overprint the $\mathrm{D} 2$ fabric but also form in the otherwise undeformed granite and show similar dextral transcurrent kinematics though often with shallower or horizontal lineations, and (c) a folding and crenulation of the mylonitic and phyllonitic foliations by D3 folds, marking the end of ductile shear (Fig. 11). Shear sense criteria and the shallow to sub-horizontal lineations consistently show oblique dextral-reverse sense of movement in this area, often with a strong strike-slip component (Fig. 10 plot IIe). Mean movement direction is towards $240-280^{\circ}$, which is very similar to the extension direction at the Simplon fault and strike-slip movements in the Rhône valley (Mancktelow 1985; Hubbard and Mancktelow 1992).

\section{Major faults and brittle deformation}

In order to critically assess the potential for young uplift on the major fault zones, activity on these deformation zones is considered in this next chapter in terms of overprinting relationships that can be established from the chronology of deformation described in Sect. 3. Furthermore, evidence for young movements associated with these known fault zones, mainly expressed as brittle deformation, is discussed 


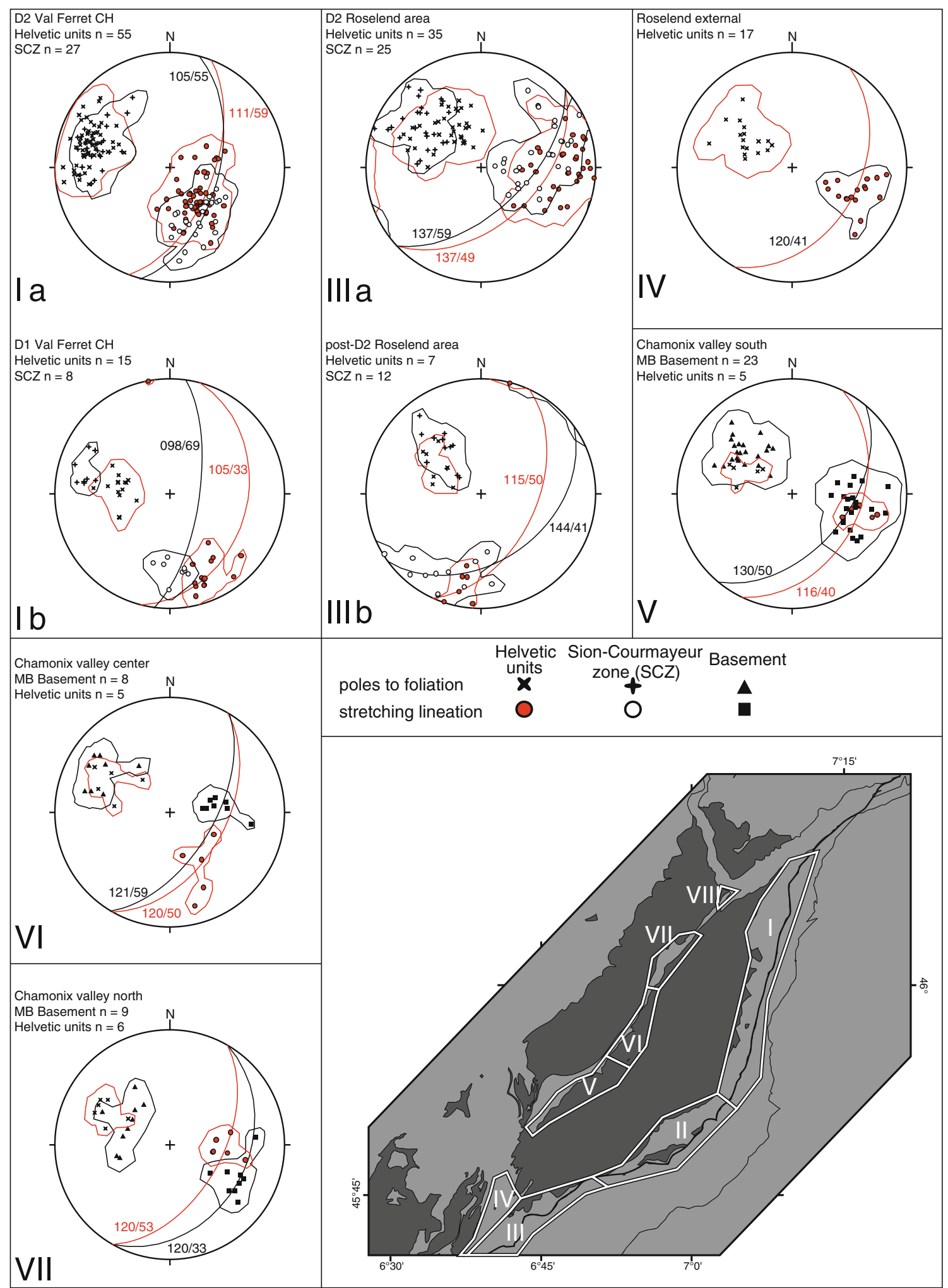

Fig. 9 Structural data for ductile shearing, separated into 8 areas. For each separate region stereographic projections of poles to planes and lineations are given (Schmidt, lower hemisphere). Great circles and their labels represent the mean orientation of the foliation (dip direction/dip). Red great circles correspond to the foliation in the
Helvetic meta-sediments, black great circles correspond to the foliation in the basement or Sion-Courmayeur zone units, according to stereogram label. For areas II and VIII see Fig. 10. The projections are coded for lithologies where appropriate according to the legend 


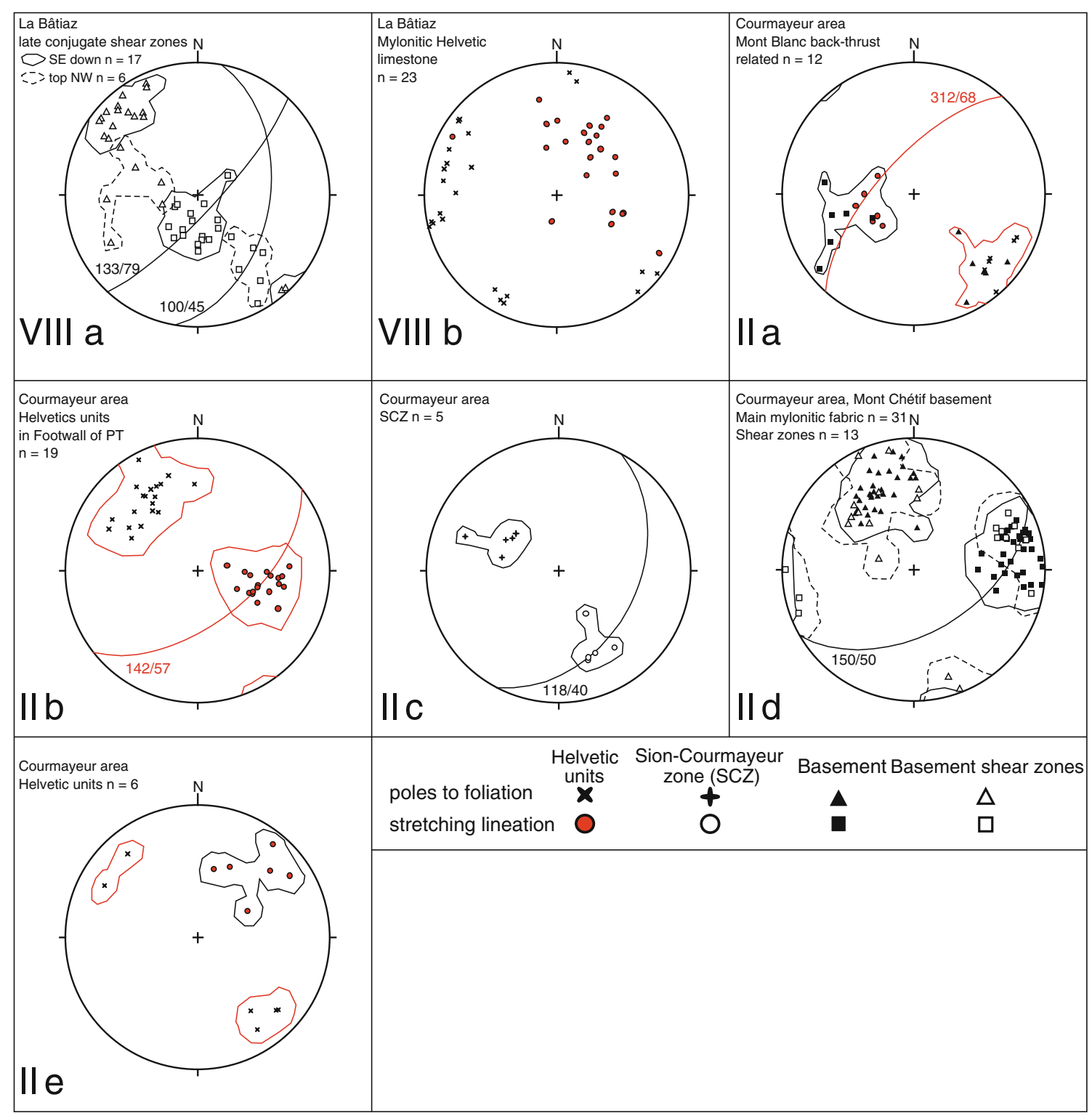

Fig. 10 Structural data for ductile shearing from areas II and VIII (see caption and legend, Fig. 9)

with regard to possible late vertical displacement and young uplift.

\subsection{Penninic thrust}

The first deformation along the Penninic thrust is represented by a pervasive schistosity in the Helvetic units and a higherorder schistosity in the Sion-Courmayeur zone. Deformation in the overthrust Sion-Courmayeur zone is described in great detail by Loprieno et al. (2011) and is not the subject of this study. However, what they describe as D3 during activity along the Roselend thrust (locally corresponding to the Penninic thrust) is equivalent to D2 of this study, simultaneously deforming both footwall and hanging wall of the Penninic thrust. This out-of-sequence activity is similar to that on the
Diablerets thrust as well as to the formation of S2 in the Chamonix zone. Sense of movement can be unequivocally established all along the Penninic thrust in the study area and shows exclusively $\sim$ top-to-NW movements in the northern parts of the study area and top-to-W in the southern parts. Normal fault reactivation, as proposed by Seward and Mancktelow (1994), could not be confirmed anywhere and significant uplift of the external massifs relative to the Penninic zone by means of normal faulting seems very unlikely along this part of the Penninic thrust.

\subsection{Mont Blanc back-thrust/-fold}

Field observations confirm evidence for both folding and thrusting/shearing along the Mont Blanc back-thrust (Steck 


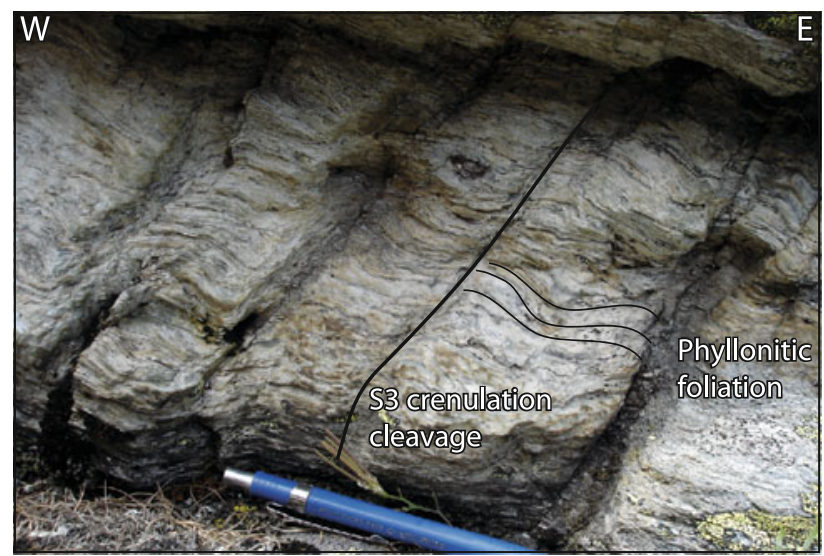

Fig. 11 D3 crenulation overprinting a phyllonitic shear zone in the Mont Chétif area (phyllonitic foliation 106/30, S3 295/70) [561843/ 071947]

et al. 2001; Leloup et al. 2005; Egli 2013). In general, the ESE basement-cover contact shows a gradual change in the dip orientation, from SE to NW and back to SE going from the Glacier de la Miage to the northern end of the Italian Val Ferret. No lateral fault structures or rapid change in orientation are observed, indicating that it is initially a broadly back-folded contact (Steck et al. 2001). However, the cover rocks at the Mont Blanc back-thrust are clearly affected by reactivation of this structure, resulting in sheared and cataclastic zones related to later movements. The fault plane itself is locally also slightly folded and crosscut by a weak fabric most probably associated with D3 (Fig. 12a). The definition of a Mont Blanc back-thrust therefore only considers one aspect of a more complex history involving both thrusting and back-folding, which together could very possibly cause significant uplift. However, very recent activity causing significant vertical motion appears unlikely because late brittle deformation is restricted to smaller displacements, which usually indicate dextral strike-slip kinematics (Fig. 12b). Even though there is certainly a component of back-thrusting, relative uplift of the Mont Blanc massif along its southern margin is largely due to folding and ductile shearing.

\subsection{Chamonix zone/Mont Blanc shear zone}

Our observations agree with the interpretation that parts of the Chamonix zone correspond to the strongly sheared sedimentary sequence on the overturned limb of a regional fold, with the Mont Blanc massif as the crystalline core (e.g. Escher et al. 1993). The several hundred metres wide shear zone includes the entire inverted sequence of the fold-nappe and a zone within the attached basement. One can refer to this sheared overturned limb as the Mont Blanc shear zone, since it corresponds to the same structure described by Leloup et al. (2005), although our
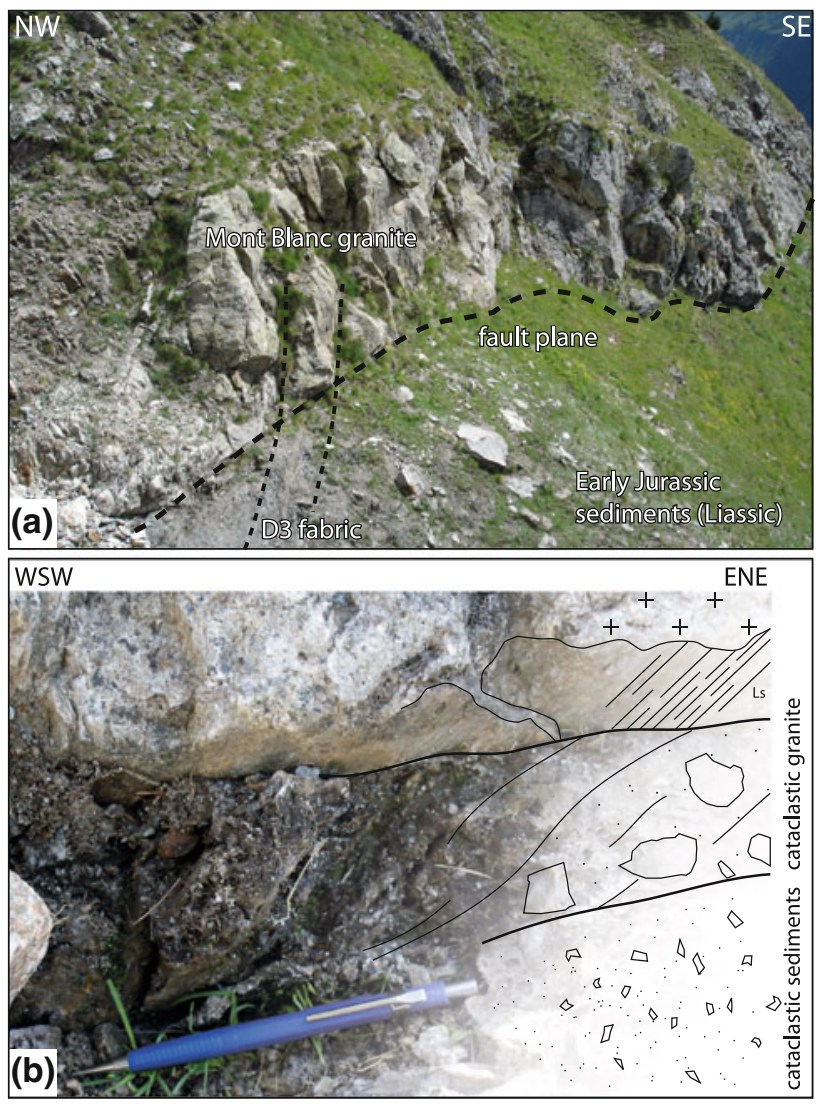

Fig. 12 a Folded thrust contact of the Mont Blanc back-thrust crosscut by the D3 fabric [566239/077665]. b Detailed photograph of the fault plane. The ductile lineation (Ls) indicates steep reverse movements whereas the brittle structures show strike-slip kinematics [566246/077682]. Pictures are located at the basement-cover contact north of Praz Sec. See also Fig. 4

interpretation is different (see below). Foliations in the basement and the adjacent cover are (sub-)parallel and are most likely to have developed in the same deformation, with a consistent SE-dipping orientation and a WNWdirected thrust sense of movement. The partly mylonitic cover rocks, which were already observed by Bellière (1956), are interpreted to be evidence for collective shear of cover and basement without large localized offset across the overturned stratigraphic contact. There is a strong deformation gradient from the basement-cover contact into the basement rocks, as shown by the three examples in Fig. 13a) strongly sheared basement directly at the contact, b) less deformed basement still showing a clear Alpine overprint and c) basement practically unaffected by Alpine deformation, with pre-Alpine foliation and folds, as well as undeformed aplitic dykes with an age presumably similar to the Mont Blanc granite ( $200 \mathrm{Ma}$; Bussy et al. 1989; von Raumer et al. 1993). There is no evidence for young (post-mid-Miocene) activity as demonstrated by the observations that a) the basement mylonites show mid- 

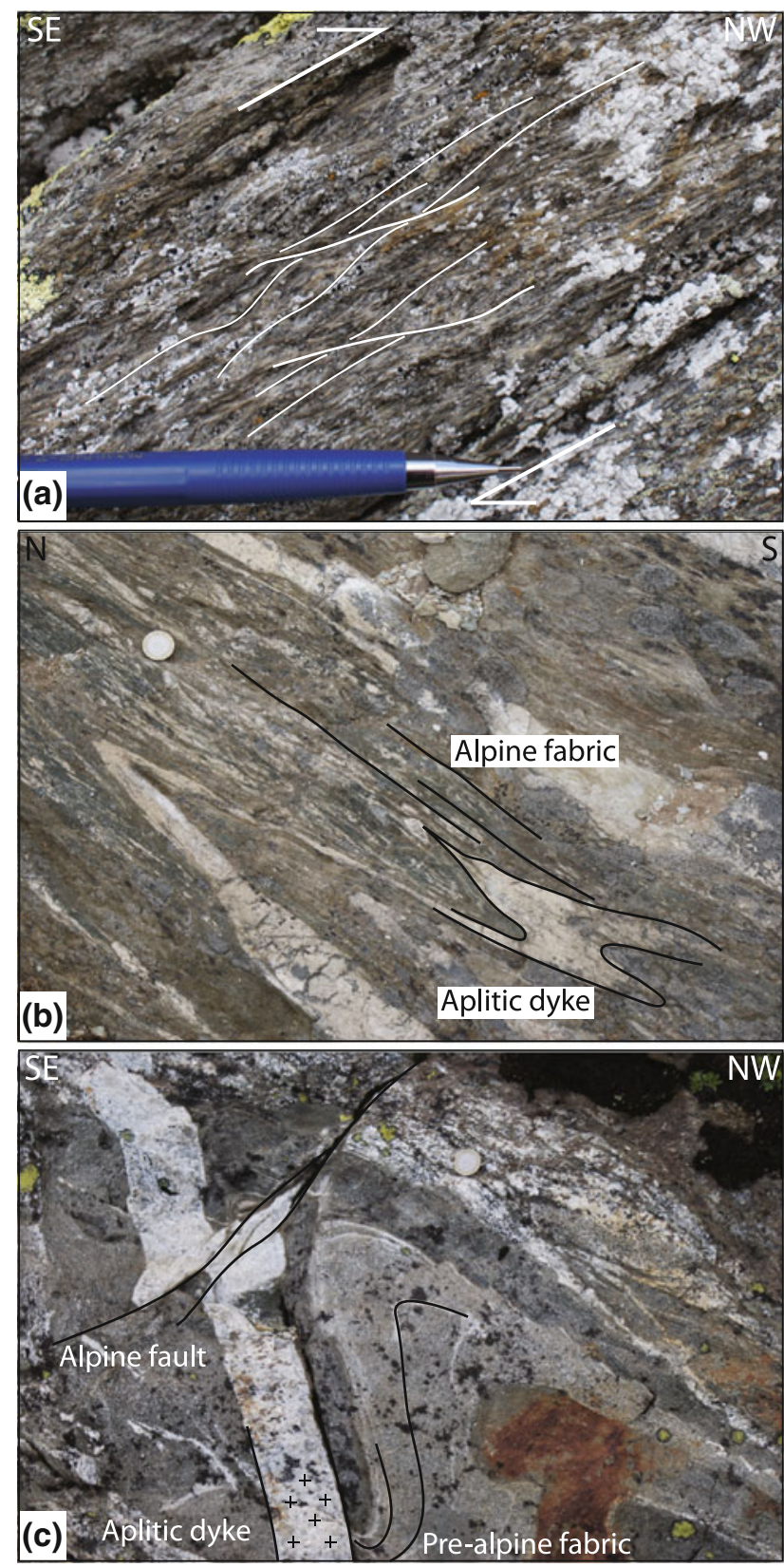

Fig. 13 Gradient in Alpine deformation within the Mont Blanc shear zone. a Strongly sheared granite close to the basement-cover contact at Col de Balme [563843/097237]. b Folded aplitic dyke and strong Alpine fabric $\sim 400 \mathrm{~m} \mathrm{SE}$ of the Plan de l'Aiguille cable-car station [557308/083104]. c Preserved pre-Alpine structures cut by aplitic dykes unaffected by Alpine deformation $\sim 600 \mathrm{~m} \mathrm{SW}$ of the Plan de l'Aiguille cable-car station [557363/082891]. One euro piece for scale

greenschist conditions with biotite stable during shear, which is close to the maximum conditions actually reached during Alpine deformation (e.g. von Raumer and Bussy 2004), and b) shear-related structures in the meta-sediments show no late overprint indicating recent thrusting.

Despite the strong morphological expression of the Simplon-Rhône fault into the Chamonix valley, overall transcurrent displacement in the Chamonix zone appears to be rather small. Evidence for dextral transcurrent movement has been presented by Gourlay and Ricou (1983), who make a maximum estimate of 5-15 km dextral displacement for the southern end of the Chamonix valley, and Hubbard and Mancktelow (1992) for the northern part at $\mathrm{Col}$ de Forclaz. Although dextral strike-slip movements occurring along the Chamonix zone are not in question, there is no structural evidence for large displacements. Late right-lateral movements are restricted to a fairly narrow zone that is at most a few hundred metres wide and located in the vicinity of the basement-cover contact. Brittle structures, such as calcite-slickenfibres, are by far the most common expression of these late movements, although brittle-ductile transitional behaviour (e.g., en-echelon sigmoidal veins) can also be observed. The many small faults may add up to significant displacements, but the overall dextral displacement between the Aiguilles Rouges and Mont Blanc massifs, though difficult to estimate, is still interpreted to be on the order of a few kilometres at most.

\subsection{Late collapse folds and brittle deformation}

In some areas (e.g. Mont Joly between the Belledonne and Mont Blanc massifs, Swiss Val Ferret), the previously steepened schistosity is overprinted by collapse-type folds (e.g. Froitzheim 1992) with sub-horizontal axial planes. However, such folds occur only locally and cannot be observed systematically in the region. In contrast, brittle deformation is very common throughout the study area. The most common manifestations of brittle deformation are striated faults with fibrous mineralisation of quartz or calcite, typically exposed on the $\mathrm{cm}$ - to $\mathrm{m}$-scale and showing only minor offsets. Fault surfaces with slickensides are abundant throughout the entire area but with variable orientations and senses of movement. Dextral strike-slip faults are the most common, occasionally accompanied by sinistral faults as conjugate sets. Late faults showing significant vertical displacement are rare. The dominance of dextral strike-slip faults obviously reflects regional-scale right-lateral movements on both sides of the massif. Two main pairs of orientations can be observed for dextral and sinistral faults, influenced both by regional variation and lithology. The first pair has dextral faults striking roughly E-W and sinistral faults striking NNW-SSE. The second pair is rotated $\sim 60^{\circ}$ counterclockwise relative to the first set, with NNE-SSW striking dextral and WSW-ENE striking sinistral faults. The basement rocks of Mont Blanc, Belledonne and Mont Chétif mainly contain faults of the first set, which generally dominate throughout most parts of the study area. However, in the NE of the study area and especially in the cover units, the second fault set is observed. This leads to a 
significant difference in the results of fault-slip analysis and palaeo-stress reconstruction.

\subsection{Fault-slip analysis on fractures}

In the present study, fault-slip data have been used to calculate stress tensors on brittle structures in different parts of the study area, i.e., on structures which post-date the structures of deformation phases D1-D3 described in Sect. 3. The conditions for stress inversion in many of the analysed locations are unfavourable because the metasediments are clearly not a homogenous rock mass, as would be required for an exact computation of stress tensors, and their strong schistosity and/or bedding could also significantly influence the formation of faults. Nevertheless, we can often observe faults which form at small angles of $10-20^{\circ}$ to the foliation, indicating that reactivation of pre-existing planes does not play a big role and that therefore most structures can be treated as an approximation to newly formed faults. Another limitation is that in many locations there is predominantly (or even exclusively) only one orientation of faults developed. Nevertheless, we performed the analyses with the necessary caution in order to obtain a qualitative result for the orientations of the axes of principal stress. Calculations were performed using the TectonicsFP software (Ortner et al. 2002). Sorting of the datasets was done manually to have good control on the selection of faults. For calculations of the stress-tensors we used the P-T-method (Turner 1953) and checked and compared the results with both the NDA (Spang 1972) and right-dihedra (Angelier and Mechler 1977) methods. For every shear plane a contraction (P-axis) and an extension axis (T-axis) is constructed on an auxiliary plane perpendicular to the shear plane and parallel to the slip direction (Online Resource 1). The P-, $\mathrm{T}$ - and intermediate $\mathrm{B}$-axis are perpendicular to each other and these kinematic axes are interpreted as an approximation to the principal axes of stress $\sigma 1(\mathrm{P}), \sigma 2(\mathrm{~B})$ and $\sigma 3$ (T). In this study, 279 fault-lineation pairs were selected and 26 tensors were calculated for locations around the Mont Blanc massif and the horizontal projections of the P-axes are indicated with arrows on Fig. 14 (in two cases of steep P-axes, the T-axes are indicated). In some cases, to increase the amount of data used for the single calculations, measurements from several nearby outcrops were combined. This was only done when block rotations or other disturbances between the outcrops could be ruled out. Lack of data from a specific area reflects bad outcrop conditions. The resulting tensors cluster around two different orientations with variation due to lithology and the spatial distribution. The two orientations of the P-axis (i.e., $\sim \sigma 1$ ) are roughly ENE-WSW and ESE-WNW with a shallow plunge. Almost all the faults have steep B-axes $(\sim \sigma 2)$ and therefore indicate transcurrent kinematics. Generally one can say that the less common ENE-WSW orientation of the P-axis is only present on the northeast side of the Mont Blanc massif in the cover units whereas the ESE-WNW orientation is present to the south and on the western side of the massif.

\section{Discussion}

Alpine deformation around the Mont Blanc massif was dominated by NNW to WNW directed shear in a setting of on-going shortening during D1 and D2. It is suggested that D1 and D2 structures developed in a setting of continuous shear with a counter-clockwise rotation of the general thrusting direction. Shear concentrated on both sides of the basement block, mainly along the Penninic thrust, the Diablerets thrust and the Mont Blanc shear zone, showing intense shearing during D2, post-dating nappe emplacement. Crespo-Blanc et al. (1995) and Kirschner et al. (1996) argue that ductile shear along the Diablerets thrust and the base of the Morcles nappe ceased around 15-17 Ma, which would mean that the main shearing in the study area also took place before that time (i.e. in Early to mid-Miocene times). NNW-directed movements and the formation of a recumbent large-scale fold during D1 were followed by more NW- to WNW-directed thrusting during D2, which varied very little between the southern and northern parts of the massif. The inverted sequence along the Chamonix zone and the upright limb in the Swiss Val Ferret show consistent thrust movements towards $290-310^{\circ}$. However, on the internal side to the southeast, stretching is $\mathrm{W}$ to $\mathrm{SW}$ directed and shows a significant dextral strike-slip component. The orientations of D2 related structures appear to be strongly influenced by the previously established shape of the basement block. This leads to variable stretching directions on the internal side of the massif that, however, do not indicate different overall regional kinematics. Considering an initial arcuate geometry for the Western Alps, burial and NNW-directed shearing of the basement possibly caused a lateral space problem, forming a strongly non-cylindrical fold-nappe. The two depressions at the northern and southern axial extremities of the massif preserve undeformed autochthonous cover units and there is a strain-gradient from these regions to the middle of the dome. This could be related to the development of a large-scale non-cylindrical fold and also at least in part explain the depressions north-east and south-west of the massif. Furthermore, the orientations of subsequent shear structures suggest that the Mont Blanc basement block obtained its present overall shape early in the development history of the massif and strongly influenced the orientation of later structures. Dextral 


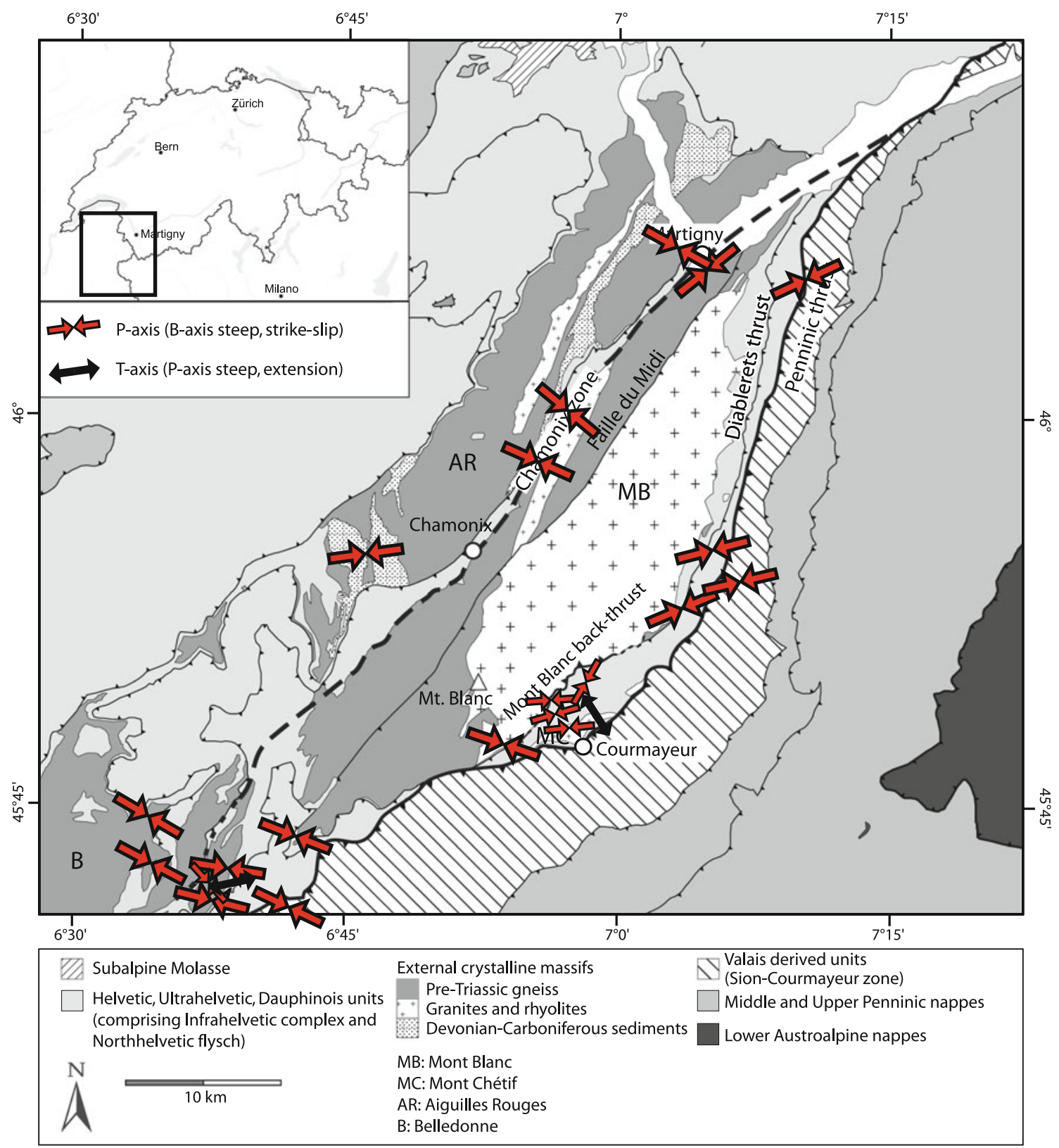

Fig. 14 Synthesis of data from fault-slip analysis on brittle faults in the study area. Palaeostress map indicating P-axes (compression direction) projected on a horizontal plane except for two calculations

transcurrent phyllonitic shear zones in the Mont Chétif basement slice, as well as the strong strike-slip component in the Col de la Seigne-Cormet de Roselend area, might be related to on-going WNW-ESE convergence, which possibly also led to tectonic thinning of parts of the Helvetic units in the area of Col de la Seigne. However, the dextral component to the generally reverse movements on the Mont Blanc back-thrust and on conjugate shear zones in the Chamonix zone, as well as late, mainly brittle dextral strike-slip movements on both sides of the Mont Blanc during its younger history, cannot be satisfactorily where the T-axes (extension direction) are shown. Most reconstructions have shallow $\mathrm{P}$ - and T-axes and therefore transcurrent kinematics. Data table in Online Resource 1

explained by a general NW-SW or WNW-ESE shortening. They are instead interpreted to be induced by WSWdirected movement of the internal units of the Alps related to deformation along the Rhône-Simplon fault system, whose activity is in part coeval with on-going NW-SE shortening (Fig. 15; e.g. Mancktelow 1992). This suggests that movements on the Rhône-Simplon fault system were distributed into two zones of deformation that extend both into the Chamonix valley and into the Val Ferret. The faultslip analyses suggest that the stress field in the area northeast of the Mont Blanc massif locally changed to ENE- 


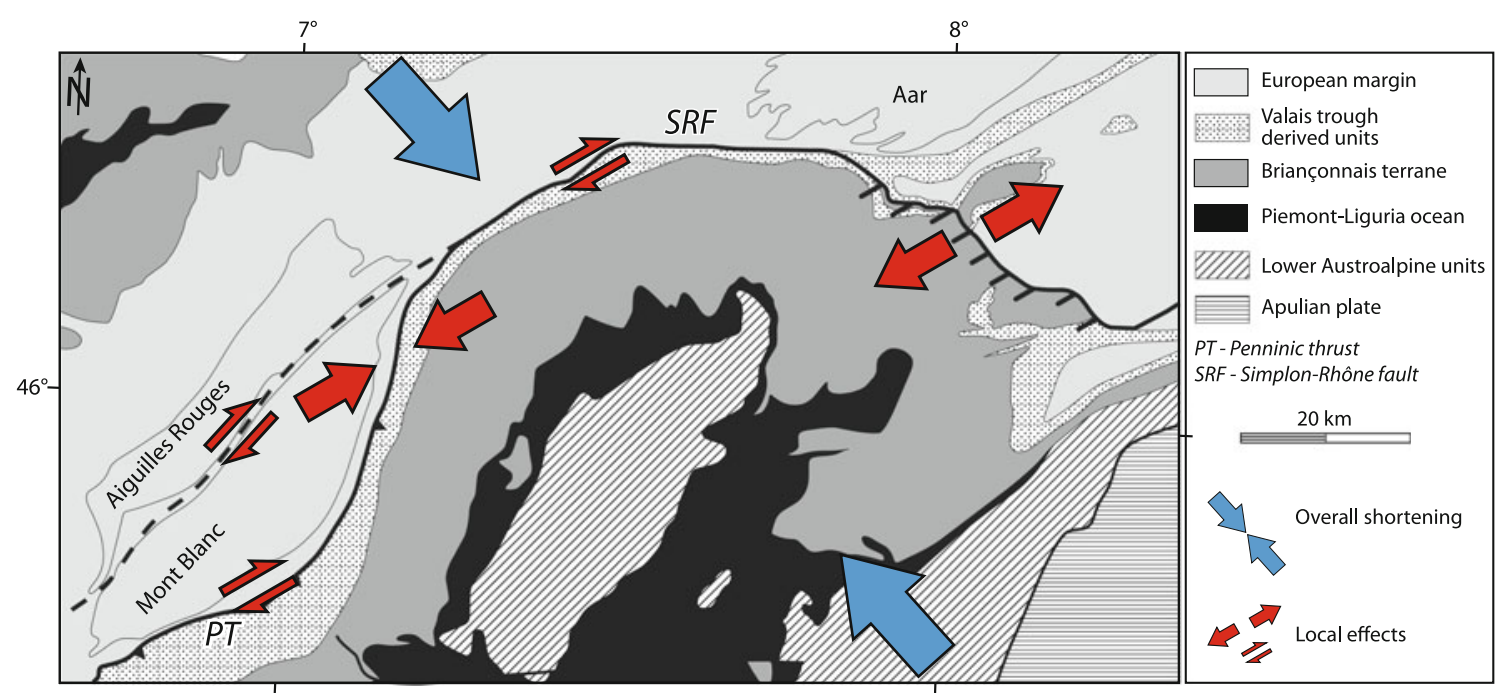

Fig. 15 Tectonic map of the Simplon-Rhône valley to Mont Blanc region indicating the overall shortening direction (blue arrows) and local tectonic responses (red arrows: extension, strike-slip)

WSW compression. This can be directly related to movements on the Rhône-Simplon fault system, with the Mont Blanc lying in a restraining bend position relative to the Penninic Alps. We can establish in this study that longlasting dextral transcurrent deformation has continued since the Miocene, initially on ductile shear zones but transitional to brittle structures during younger deformation. However, the strike-slip deformation on the southeastern side of the Mont Blanc massif induced by WNWESE shortening and transcurrent motion related to the Rhône-Simplon fault need to be distinguished. Most of the deformation indeed takes place in the cover units around Mont Blanc. However, based on relative age relationships from D3 overprinting patterns, it can be inferred that the main movements on the major faults framing the massif cannot be very young but rather of mid-Miocene age. The youngest structures are brittle, show small displacements, are more distributed through the area, and are not related to major fault zones. We therefore propose that young uplift is widely distributed over a broader area including the surrounding regions and is not focused on a few major faults bounding the Mont Blanc massif causing isolated uplift of the massif.

\section{Conclusions}

This study demonstrates that no major tectonic structures around the Mont Blanc massif show very young activity and therefore that young uplift and exhumation of the massif cannot be directly linked to such discrete structures. Most vertical motion along the major shear zones and thrusts took place in Miocene times and there is no structural evidence for young localized exhumation. The geometry of the massif already formed in the early stages of deformation in the Helvetic domain (Oligocene and early Miocene; cf. Fig. 8-4 of Pfiffner 2011) and strongly influenced later structures during on-going shortening. The position of the massif in the bend of the western Alps plays an important role. In this specific region, NW-SE shortening interferes with orogen-parallel extension along the Rhône-Simplon fault system, leading to the development of a local restraining bend between the internal Alps and the Mont Blanc massif. The question remains as to what causes the strong exhumation signal in the last $2 \mathrm{Ma}$, as indicated from modelling of thermochronology data. The lack of evidence for tectonic control of recent localized uplift of the Mont Blanc massif directly favours an alternative scenario of enhanced erosion and denudation during a more regionally distributed uplift, possibly related to glaciation, as has also been proposed by Glotzbach et al. $(2008,2011)$ and Fox (2012).

Acknowledgments We thank A. Pfiffner and B. Fügenschuh for detailed and constructive reviews and G. Milnes for valuable suggestions and the editorial handling, which helped to significantly improve an earlier version of the manuscript. The Fondazione Montagna Sicura (Courmayeur) is thanked for their hospitality during the field campaigns. This study was part of the collaborative TopoAlps project under the auspices of the European Science Foundation (ESF) Eurocores Programme TOPO-EUROPE, and was funded by the Swiss National Science Foundation (SNF projects 200021-134469 and 200021-120502).

\section{References}

Angelier, J., \& Mechler, P. (1977). Sur une méthode graphique de recherche des constraintes principales également utilisable en tectonique et en séismologie: la méthode des dièdres droits. Bulletin de la Societe Geologique de France, XIX, 1309-1318. 
Antoine, P. (1971). La zone des Brèches de Tarentaise entre Bourg Saint-Maurice (vallée de l'Isère) et la frontière italo-suisse. Travaux du Laboratoire de géologie de la Faculté des sciences de Grenoble, Mémoires, 9, 1-367.

Antoine, P., Pairis, J.-L., \& Pairis, B. (1975). Quelques observations nouvelles sur la structure de la couverture sédimentaire interne du massif du Mont-Blanc, entre le col Ferret (frontière italosuisse) et la Tête des Fours (Savoie, France). Géologie Alpine, $51,5-23$.

Argand, E. (1911). Les nappes de recouvrement des Alpes Pennines et leurs prolongements structuraux, Beiträge zur geologischen Karte der Schweiz. Neue Folge, 31, 1-25.

Argand, E. (1916). Sur l'arc des Alpes occidentales. Eclogae Geologicae Helvetiae, 14, 145-191.

Ayrton, S. (1980). La geologie de la zone Martigny-Chamonix (versant suisse) et l'origine de la nappe de Morcles (un exemple de subduction continentale). Eclogae Geologicae Helvetiae, 73, 137-172.

Bellière, J. (1956). Caractère de la déformation Alpine dans les schistes cristallins du massif du Mont-Blanc. Bulletin de la Societe Geologique de France, 6, 691-698.

Bellière, J. (1988). On the age of mylonites within the Mont Blanc massif. Geodinamica Acta, 2, 13-16.

Bogdanoff, S., Michard, A., Mansour, M., \& Poupeau, G. (2000). Apatite fission track analysis in the Argentera massif: evidence of contrasting denudation rates in the External Crystalline Massifs of the Western Alps. Terra Nova, 12, 117-125.

Burkhard, M. (1988). L'Helvétique de la bordure occidentale du massif de l'Aar (Évolution tectonique et métamorphique). Eclogae Geologicae Helvetiae, 81, 63-114.

Burkhard, M., \& Sommaruga, A. (1998). Evolution of the western Swiss Molasse basin: structural relations with the Alps and the Jura belt. Geological Society, London, Special Publications, 134, 279-298.

Bussy, F. (1990). Pétrogenèse des enclaves microgrenues associées aux granitoïdes calco-alcalins: exemple des massifs varisque du Mont-Blanc (Alpes occidentales) et miocène du Monte Capanne (Ile d'Elbe, Italie), Mémoires de Géologie (Lausanne), 7, 1-309.

Bussy, F., Hernandez, J., \& von Raumer, J. (2000). Bimodal magmatism as a consequence of the post-collisional readjustment of the thickened Variscan continental lithosphere (Aiguilles Rouges-Mont Blanc Massifs, Western Alps). Transactions of the Royal Society of Edinburgh-Earth Sciences, 91, 221-233.

Bussy, F., Schaltegger, U., \& Marro, C. (1989). The age of the MontBlanc granite (Western Alps): a heterogeneous isotopic system dated by $\mathrm{Rb}-\mathrm{Sr}$ whole rock determinations on its microgranular enclaves. Schweizerische Mineralogische und Petrographische Mitteilungen, 69, 3-13.

Bussy, F., \& von Raumer, J. (1993). U-Pb dating of Palaeozoic events in the Mont-Blanc crystalline massif, Western Alps., Terra Abstracts, 5(Supplement 1), 382-383.

Butler, R. W. H. (1983). Balanced cross-sections and their implications for the deep structure of the northwest Alps. Journal of Structural Geology, 5, 125-137.

Capuzzo, N., \& Bussy, F. (2000). High-precision dating and origin of synsedimentary volcanism in the Late Carboniferous SalvanDorénaz basin (Aiguilles-Rouges Massif, Western Alps). Schweizerische Mineralogische und Petrographische Mitteilungen, 80, 147-167.

Ceriani, S., Fugenschuh, B., \& Schmid, S. M. (2001). Multi-stage thrusting at the "Penninic Front" in the Western Alps between Mont Blanc and Pelvoux massifs. International Journal of Earth Sciences, 90, 685-702.

Crespo-Blanc, A., Masson, H., Sharp, Z., Cosca, M., \& Hunziker, J. (1995). A stable and 40Ar/39Ar isotope study of a major thrust in the Helvetic nappes (Swiss Alps): evidence for fluid flow and constraints on nappe kinematics. Geological Society of America Bulletin, 107, 1129-1144.

Dobmeier, C. (1996). Die variskische Entwicklung des südwestlichen Aiguilles-Rouges-Massives (Westalpen, Frankreich), Mémoires de Géologie (Lausanne), 29, 1-191.

Egli, D. (2013). Kinematics and timing of Alpine deformation in the Mont Blanc region (Western Alps). Ph.D. dissertation, ETH Zürich, Switzerland.

Eltchaninoff-Lancelot, C., Triboulet, S., Doudoux, B., Fudral, S., Rampnoux, J.-P., \& Tardy, M. (1982). Stratigraphie et tectonique des unités delphino-helvétiques comprises entre MontBlanc et Belledone (Savoie-Alpes occidentales): implications régionales. Bulletin de la Societe Geologique de France, 24, $817-830$.

Epard, J.-L. (1986). Le contact entre le socle du Mont-Blanc et la zone de Chamonix: implications tectoniques. Bulletin de la Société vaudoise des Sciences naturelles, 78, 225-245.

Epard, J.-L. (1990). La nappe de Morcles au sud-ouest du MontBlanc, Mémoires de Géologie (Lausanne), 8, 1-165.

Escher, A., Hunziker, J. C., Marthaler, M., Masson, H., Sartori, M., \& Steck, A. (1997). Geologic framework and structural evolution of the western Swiss-Italian Alps. In O. A. Pfiffner, P. Lehner, P. Heitzmann, S. Mueller, \& A. Steck (Eds.), Deep structure of the Swiss Alps-results from NRP 20 (pp. 205-221). Basel: Birkhäuser.

Escher, A., Masson, H., \& Steck, A. (1993). Nappe geometry in the Western Swiss Alps. Journal of Structural Geology, 15, 501-509.

Fischer, H., \& Villa, I. M. (1990). Erste K/Ar- und 40Ar/39ArHornblende-Mineralalter des Taveyannaz-Sandsteins. Schweizerische Mineralogische und Petrographische Mitteilungen, 70, $73-75$.

Fox, M. (2012). The inversion of low-temperature thermochronometry to extract spatially and temporally varying exhumation rates within the Alps. Ph.D. dissertation, ETH Zürich, Switzerland.

Fricker, P. E. (1960). Geologie der Gebirge zwischen Val Ferret und Combe de l'A (Wallis). Eclogae Geologicae Helvetiae, 53, $3-132$.

Froitzheim, N. (1992). Formation of recumbent folds during synorogenic crustal extension (Austroalpine nappes, Switzerland). Geology, 20, 923-926.

Froitzheim, N., Schmid, S. M., \& Frey, M. (1996). Mesozoic paleogeography and the timing of eclogite-facies metamorphism in the Alps: a working hypothesis. Eclogae Geologicae Helvetiae, 89, 81-110.

Fügenschuh, B., Loprieno, A., Ceriani, S., \& Schmid, S. M. (1999). Structural analysis of the Subbriançonnais and Valais units in the area of Moûtiers (Savoy, Western Alps): paleogeographic and tectonic consequences. International Journal of Earth Sciences, $88,201-218$.

Fügenschuh, B., \& Schmid, S. M. (2003). Late stages of deformation and exhumation of an orogen constrained by fission-track data: a case study in the Western Alps. Geological Society of America Bulletin, 115, 1425-1440.

Funk, H., Oberhänsli, R., Pfiffner, A., Schmid, S., \& Wildli, W. (1987). The evolution of the Northern Margin of Tethys in Eastern Switzerland. Episodes, 10, 102-106.

Glotzbach, C., Reinecker, J., Danišík, M., Rahn, M., Frisch, W., \& Spiegel, C. (2008). Neogene exhumation history of the Mont Blanc massif, western Alps. Tectonics, 27, TC4011. doi:10.1029/ 2008 TC002257.

Glotzbach, C., van der Beek, P. A., \& Spiegel, C. (2011). Episodic exhumation and relief growth in the Mont Blanc massif. Western Alps from numerical modelling of thermochronology data. Earth and Planetary Science Letters, 304, 417-430. 
Goffé, B., \& Bousquet, R. (1997). Ferrocarpholite, chloritoïde et lawsonite dans les métapélites des unités du Versoyen et du Petit St Bernard (zone valaisanne, Alpes occidentales) = Ferracarpholite, chloritoid and lawsonite in metapelites of the Versoyen and Petit St Bernard units (Valais zone, Western Alps). Schweizerische Mineralogische und Petrographische Mitteilungen, 77, 137-147.

Goffé, B., Schwartz, S., Lardeaux, J. M., \& Bousquet, R. (2004). Explanatory notes to the map: metamorphic structure of the Alps. Mitteilungen der Österreichischen Mineralogischen Gesellschaft, 149, 125-144.

Gourlay, P., \& Ricou, L.-E. (1983). Le jeu décrochant dextre tardif de la suture de Chamonix (Alpes françaises suisses). Comptes Rendus de l'Académie des sciences Paris, 296, 927-932.

Grasmück, K. (1961). Die helvetischen Sedimente am Nordostrand des Mont Blanc-Massivs (zwischen Sembrancher und dem Col Ferret). Eclogae Geologicae Helvetiae, 54, 351-450.

Guermani, A., \& Pennacchioni, G. (1998). Brittle precursors of plastic deformation in a granite: an example from the Mont Blanc massif (Helvetic, western Alps). Journal of Structural Geology, 20, 135-148

Heim, A. (1921). Geologie der Schweiz, Chr. Herm. Tauchnitz, Leipzig.

Herb, R. (1988). Eocaene Paläogegographie und Paläotektonik des Helvetikums. Eclogae Geologicae Helvetiae, 81, 611-657.

Hubbard, M., \& Mancktelow, N. S. (1992). Lateral displacement during Neogene convergence in the western and central Alps. Geology, 20, 943-946.

Huon, S., Burkhard, M., \& Hunziker, J.-C. (1994). Mineralogical, $\mathrm{K} / \mathrm{Ar}$, stable and $\mathrm{Sr}$ isotope systematics of $\mathrm{K}$-white micas during very low-grade metamorphism of limestones (Helvetic nappes, western Switzerland). Chemical Geology, 113, 347-376.

Jeanbourquin, P. (1994). Early deformation of ultrahelvetic mélanges in the helvetic nappes (Western Swiss Alps). Journal of Structural Geology, 16, 1367-1383.

Jeanbourquin, P., \& Goy-Eggenberger, D. (1991). Mélanges suprahélvetiques: sédimentation et tectonique au front de la nappe de Morcles (Vaud, Suisse). Géologie Alpine, 67, 43-62.

Kempf, O., \& Pfiffner, O. A. (2004). Early Tertiary evolution of the North Alpine Foreland Basin of the Swiss Alps and adjoining areas. Basin Research, 16, 549-567.

Kirschner, D. L., Cosca, M. A., Masson, H., \& Hunziker, J. C. (1996). Staircase $40 \mathrm{Ar} / 39 \mathrm{Ar}$ spectra of fine-grained white mica: timing and duration of deformation and empirical constraints on argon diffusion. Geology, 24, 747-750.

Kirschner, D. L., Sharp, Z. D., \& Masson, H. (1995). Oxygen isotope thermometry of quartz-calcite veins: unraveling the thermaltectonic history of the subgreenschist facies Morcles nappe (Swiss Alps). Geological Society of America Bulletin, 107, $1145-1156$.

Lateltin, O., \& Müller, D. (1987). Paleogeographic Evolution of the Taveyannaz Sandstone Basin in the Aravis Mountains (HauteSavoie) at the End of the Paleogene. Eclogae Geologicae Helvetiae, 80, 127-140.

Leloup, P. H., Arnaud, N., Lacassin, R., \& Sobel, E. R. (2007). Reply to comment by Y. Rolland et al. on "Alpine thermal and structural evolution of the highest external crystalline massif: The Mont Blanc". Tectonics, 26, TC2016. doi:10.1029/ 2006TC002022.

Leloup, P. H., Arnaud, N., Sobel, E. R., \& Lacassin, R. (2005). Alpine thermal and structural evolution of the highest external crystalline massif: The Mont Blanc. Tectonics, 24, TC4002. doi:10. 1029/2004TC001676.

Loprieno, A., Bousquet, R., Bucher, S., Ceriani, S., Dalla Torre, F. H., Fugenschuh, B., \& Schmid, S. M. (2011). The Valais units in
Savoy (France): a key area for understanding the palaeogeography and the tectonic evolution of the Western Alps. International Journal of Earth Sciences, 100, 963-992.

Malusa, M. G., Polino, R., Zattin, M., Bigazzi, G., Martin, S., \& Piana, F. (2005). Miocene to Present differential exhumation in the Western Alps: Insights from fission track thermochronology. Tectonics, 24, TC3004. doi:10.1029/2004TC001782.

Mancktelow, N. S. (1985). The Simplon Line: a major displacement zone in the western Lepontine Alps. Eclogae Geologicae Helvetiae, 78, 73-96.

Mancktelow, N. S. (1992). Neogene lateral extension during convergence in the Central Alps: evidence from interrelated faulting and backfolding around the Simplonpass (Switzerland). Tectonophysics, 215, 295-317.

Masson, H., Herb, R., \& Steck, A. (1980). Helvetic Alps of Western Switzerland. In R. Trümpy (Ed.), Geology of Switzerland, a guide book (Part B) (pp. 109-153). Basel: Wepf and Co.

Mugnier, J. L., Loubat, H., \& Cannic, S. (1993). Correlation of seismic images and geology at the boundary between internal and external domains of the Western Alps. Bulletin de la Societe Geologique de France, 164, 697-708.

Oberhänsli, R., Bousquet, R., Engi, M., Goffé, B., Gosso, G., Handy, M., Höck, V., Koller, F., Lardeaux, J.-M., Polino, R., Rossi, P., Schuster, R., Schwarz, S. \& Spalla, M. I. (2004). Metamorphic structure of the Alps. Paris: Commission for the Geological Map of the World.

Ortner, H., Reiter, F., \& Acs, P. (2002). Easy handling of tectonic data: the programs TectonicVB for Mac and TectonicsFP for Windows(TM). Computers \& Geosciences, 28, 1193-1200.

Paréjas, E. (1922). Géologie de la zone de Chamonix comprise entre le Mont-Blanc et les Aiguilles Rouges. Mémoires de la Société de physique et d'histoire naturelle de Genève, 39, 373-442.

Perello, P., Piana, F., \& Martinotti, G. (1999). Neo-Alpine structural features at the boundary between the Penninic and Helvetic domains (Pre S. Didier Entreves, Aosta valley, Italy). Eclogae Geologicae Helvetiae, 92, 347-359.

Pfiffner, O. A. (2011). Structural Map of the Helvetic Zone of the Swiss Alps, including Vorarlberg (Austria) and Haute Savoie (France), 1:100000. Geological Special Map 128. Explanatory notes. Wabern: Swisstopo.

Platt, J. P. (1984). Balanced cross-sections and their implications for the deep structure of the northwest Alps: discussion. Journal of Structural Geology, 6, 603-606.

Rolland, Y., Corsini, M., Rossi, M., Cox, S. F., Pennacchioni, G., Mancktelow, N. S., \& Boullier, A. M. (2007). Comment on "Alpine thermal and structural evolution of the highest external crystalline massif: the Mont Blanc" by P. H. Leloup, N. Arnaud, E. R. Sobel, and R. Lacassin. Tectonics, 26, TC2015. doi:10. 1029/2006TC001956.

Rolland, Y., Rossi, M., Cox, S. F., Corsini, M., Mancktelow, N. S., Pennacchioni, G., et al. (2008). 40Ar/39Ar dating of synkinematic white mica: insights from fluid-rock reaction in low-grade shear zones (Mont Blanc Massif) and constraints on timing of deformation in the NW external Alps. Geological Society, London, Special Publications, 299, 293-315.

Rossi, M., Rolland, Y., Vidal, O., \& Cox, S. F. (2005). Geochemical variations and element transfer during shear-zone development and related episyenites at middle crust depths: insights from the Mont Blanc granite (French-Italian Alps). Geological Society, London, Special Publications, 245, 373-396.

Ruffini, R., Cosca, M. A., d'Atri, A., Hunziker, J. C., \& Polino, R. (1995). The volcanic supply of the Taveyanne turbidites (Savoie, France): a riddle for Tertiary Alpine volcanism. Atti delle Accademia Scienze Roma, 14, 359-376.

Schmid, S. M., Fügenschuh, B., Kissling, E., \& Schuster, R. (2004). Tectonic map and overall architecture of the Alpine orogen. Eclogae Geologicae Helvetiae, 97, 93-117. 
Seward, D., \& Mancktelow, N. S. (1994). Neogene kinematics of the central and western Alps: evidence from fission-track dating. Geology, 22, 803-806.

Simon-Labric, T., Rolland, Y., Dumont, T., Heymes, T., Authemayou, C., Corsini, M., et al. (2009). 40Ar/39Ar dating of Penninic Front tectonic displacement (W Alps) during the Lower Oligocene (31-34 Ma). Terra Nova, 21, 127-136.

Soom, M. (1990). Abkühlungs- und Hebungsgeschichte der Externmassive und der penninischen Decken beidseits der SimplonRhone-Linie seit dem Oligozän : Spaltspurdatierungen an Apatit/ Zirkon und K-Ar-Datierungen an Biotit/Muskowit (Westliche Zentralalpen). Ph.D. dissertation, University Bern, Switzerland.

Spang, J. H. (1972). Numerical method for dynamic analysis of calcite twin Lamellae. Geological Society of America Bulletin, 83, 467-471.

Steck, A., Epard, J.-L., Escher, A., \& Gouffon, Y. (2001). Masson, $H$. Notice explicative pour la carte tectonique des Alpes de Suisse occidentale, Wabern: Swisstopo.

Steck, A., Epard, J. L., Escher, A., Lehner, P., Marchant, R., \& Masson, H. (1997). Geological interpretation of the seismic profiles through Western Switzerland : Rawil (W1), Val d'Anniviers (W2), Mattertal (W3), Zmutt-Zermatt-Findelen (W4) and Val de Bagnes (W5). In O. A. Pfiffner, P. Lehner, P. Heitzmann, S. Mueller, \& A. Steck (Eds.), Deep structure of the Swiss Alps-results from NRP 20 (pp. 123-137). Basel: Birkhäuser.

Steck, A., \& Hunziker, J. (1994). The Tertiary structural and thermal evolution of the Central Alps-compressional and extensional structures in an orogenic belt. Tectonophysics, 238, 229-254.
Sue, C., \& Tricart, P. (1999). Late Alpine brittle extension above the Frontal Pennine Thrust near Briancon. Western Alps, Eclogae Geologicae Helvetiae, 92, 171-181.

Trümpy, R. (1951). Sur les racines helvétiques et les «Schistes lustrés» entre le Rhône et la Vallée de Bagnes (Région de la Pierre Avoi). Eclogae Geologicae Helvetiae, 44, 338-347.

Trümpy, R. (1954). La zone de Sion-Courmayeur dans le haut Val Ferret valaisan. Eclogae Geologicae Helvetiae, 47, 316-359.

Turner, F. J. (1953). Nature and dynamic interpretation of deformation lamellae in calcite of three marbles. American Journal of Science, 251, 276-298.

Vernon, A. J., van der Beek, P. A., Sinclair, H. D., \& Rahn, M. K. (2008). Increase in late Neogene denudation of the European Alps confirmed by analysis of a fission-track thermochronology database. Earth and Planetary Science Letters, 270, 316-329.

von Raumer, J. F. (1971). Das Mont-Blanc-Massiv: altkristallin im Bereich schwacher alpiner Metamorphose. Schweizerische Mineralogische und Petrographische Mitteilungen, 51, 193-225.

von Raumer, J., \& Bussy, F. (2004). Mont Blanc and Aiguilles Rouges; geology of their polymetamorphic basement (External massifs, Western Alps, France-Switzerland). Mémoires de Géologie (Lausanne), 42, 1-203.

von Raumer, J. F., Ménot, R.-P., Abrecht, J., \& Biino, G. (1993). The Pre-Alpine evolution of the external massifs. In J. F. Von Raumer \& F. Neubauer (Eds.), Pre-mesozoic geology in the Alps (pp. 251-254). Berlin: Springer. 